\title{
Article \\ Influence of Environmental Factors on Urban and Architectural Design-Example of a Former Paper Mill in Nanterre
}

\author{
Renata Jóźwik 1,*(D) and Anna Jóźwik 2,*(D) \\ 1 Department of Architectural and Urban Design, Faculty of Architecture, Warsaw University of Technology, \\ 55 Koszykowa Street, 00-659 Warsaw, Poland \\ 2 Department of Structural Design, Construction and Technical Infrastructure, Faculty of Architecture, \\ Warsaw University of Technology, 55 Koszykowa Street, 00-659 Warsaw, Poland \\ * Correspondence: renata.jozwik@pw.edu.pl (R.J.); anna.jozwik@pw.edu.pl (A.J.)
}

check for

updates

Citation: Jóźwik, R.; Jóźwik, A.

Influence of Environmental Factors on Urban and Architectural Design-Example of a Former Paper Mill in Nanterre. Sustainability 2022,

14, 86. https://doi.org/10.3390/ su14010086

Academic Editors: Elżbieta Ryńska, José Guadalupe Vargas Hernández, Janusz Marchwinski, Jan Winkler and Magdalena Grochulska-Salak

Received: 7 November 2021

Accepted: 15 December 2021

Published: 22 December 2021

Publisher's Note: MDPI stays neutral with regard to jurisdictional claims in published maps and institutional affiliations.

Copyright: (c) 2021 by the authors. Licensee MDPI, Basel, Switzerland. This article is an open access article distributed under the terms and conditions of the Creative Commons Attribution (CC BY) license (https:/ / creativecommons.org/licenses/by/ $4.0 /)$.

\begin{abstract}
Biophilic design is developed in urban planning concepts for cities-in line with sustainable development. A case study of converting a former paper mill in Nanterre into a university campus showed what factors influence the emergence of the biophilic form. The research informs the planning and design mechanisms and directs attention to the process. As a result, the study demonstrates that biophilic elements from the place-based pattern group are directly related to in-depth environmental analysis - similar to elements from the nature-based and element-based pattern groups. Together they result in a biophilic form. The element of creation is also present in the design process but is not the primary determinant of the choice of a design approach. In part, the form is adapted to the area's environmental characteristics, which result from their interaction with objective determinants. Nevertheless, the implementation is not devoid of compositional, creative, and cultural elementsthat is, it assumes the features of biophilic architecture. This fact proves that the environment can influence the creative potential in architecture and urban studies.
\end{abstract}

Keywords: urban area transformations; environmental conditions; sustainable development; biophilic architecture

\section{Introduction}

Dynamic global urbanization poses a threat to the functioning of cities. It causes socio-economic problems, degrades natural ecosystems, and negatively impacts climate change [1]. It is estimated that by 2030, approximately 9.8 billion people will inhabit cities [2]. Metropolises are responsible for $80 \%$ of greenhouse gas emissions [3]. For this reason, systemic actions are taken globally, aimed at sustainable and inclusive city development to ensure the residents' prosperity and security. Thus, environmental goals constitute an essential issue of these activities. These goals consist mainly of protecting the natural environment (including natural ecosystems) and mitigating the climate change effects. Thus, shaping resilient cities is the main objective [4-11].

The most important provisions in force that affect sustainable city development have been included in the following documents: Agenda 21 (1992) [12]; the Aalborg Charter (1994) [13]; The New Athens Charter 2003, Visions for Cities in 21st Century (2003) [14]; the Leipzig Charter for the Sustainable Development of European Cities (2008) [15] and the New Leipzig Charter-the transformative power of cities for the common good (2020) [16] drawing attention to the cultural importance of cities; the provisions of the conference for sustainable development, "The Future We Want" (2012) [17]; the 2030 Agenda for sustainable urban development (2015) [18]; the Paris Agreements-United Nations Conference on Climate Change (2015) [19]; the Decade of Biodiversity 2011-2020 (2010) [20]; HABITAT III; the New Urban Agenda (2016) [21]; International Decade of Action "Water for Sustainable Development" 2018-2028 (2016) [22]; a decade of ecosystem restoration 2021-2030 (2019) [23], etc. An extensive review of these documents was carried out by Hanna and Comin [24]. 
Based on the above concepts, on theoretical and disciplinary sources, and on discourses, the concepts of green cities, sustainable cities, compact cities, and smart cities are being developed.

Sustainable development largely encompasses ecological and physical environmental issues (Figure 1).

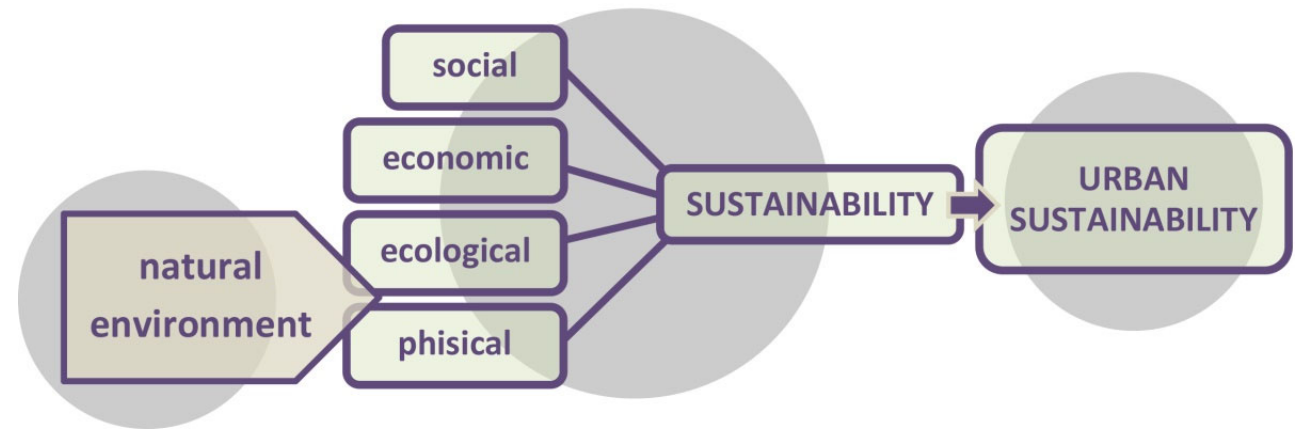

Figure 1. The diagram illustrates the main pillars of sustainable city development.

Individual countries have implemented the provisions of the agreements mentioned above in the spatial planning regulations. These, in turn, determine the directions of regional and local plans.

Brownfield sites in cities are currently being converted to new functions, in line with sustainable, inclusive urban developments. The accumulation of these investments and the scope of transformations make the mutual influence significant and subject to synergy, improving the lives of urban inhabitants and the environmental quality $[25,26]$.

At the same time, the importance of biophilic projects, such as those which link elements of nature and nature, is growing [27]. Their emergence depends on the degree of understanding and consideration of environmental factors and the ability to transform these aspects into the spatial design and shaping of areas subject to urban transformation. This impact may be observed in the application of functional and spatial solutions (on various scales: city, urban unit, place, or building), the use of safety measures to mitigate the negative effects on the environment, and the application of solutions to increase the range of ecosystem services. They create a new quality of place. In addition, the biophilic shaping of the environment emotionally engages people [28,29]. It sensitizes them to environmental issues, which stems from the primal need to connect with nature, developed over thousands of years of evolution. The basis of biophilic thinking in architectural and urban design is derived from the theory of E.O. Wilson, who defined biophilia "as man's innate emotional belonging to other living organisms" [30]. "Innate" means hereditary and, therefore, part of the ultimate human nature.

The present article formulates a hypothesis that the emphasis on improving environmental conditions (on various scales) results in a modified architectural appearance and aesthetics of the transformed urban areas, as well as in the emergence of objects that assume the "green urbanism" or "green architecture" dimensions. However, this is not the result of a reductionist approach that aims to eliminate barriers or attempts to restore a degraded urban area to the proper functioning of an environment. The creation of biophilic form is the creation of new added value. This trend is favorable for the city dwellers as a population, also due to the health-promoting properties introduced by biophilic elements.

Aesthetic issues are not entirely detached from the approach towards meeting environmental needs. Gernot Böhme develops an aesthetic concept of atmospheres to which, for example, landscapes apply. According to the theory, urban areas reflect the physical and spiritual presence of a human in space [31], which, in turn, is strongly related to human biophilic preferences [30]. Human psychological needs have been established within such theories as place attachment theory [32], restorative environmental design [33], attention restoration theory [34], stress reduction theory [35], and prospect and refuge 
theory [36]. In this regard, deliberations were made by Peters and D'Penna [37]. Tim Beatley moved the concept of biophilia to the field of urban topics and described it as "a daily dose of nature" [38]. In this case, all elements of the built environment can be biophilic [38-40]. Therefore, it can be concluded that the following factors constitute the basic premise for biophilia in cities, architecture, and design: ecological, psychological, and aesthetic (Figure 2).

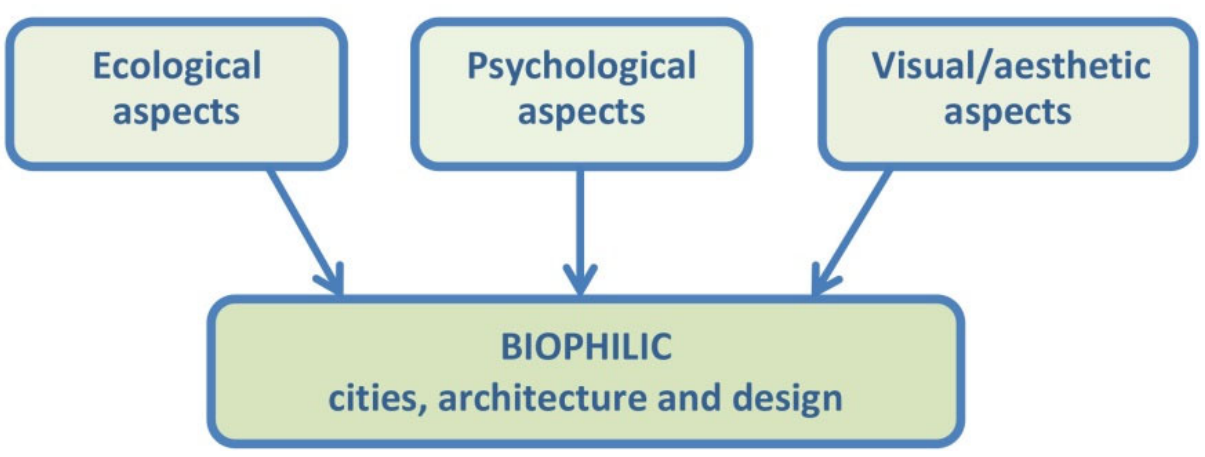

Figure 2. Factors that influence the development of biophilia in architecture and urban planning.

The following main objectives of large-scale revitalization projects include improving housing conditions, increasing employment opportunities, improving living conditions, and a wide range of environmental benefits. As a result, the following actions are taken: sustainable building development densification as part of urban-planning projects, the creation of new districts with an identity of their own, communication system and public space recognition, improving the attractiveness of the area and its surroundings, increasing the share and significance of green areas, and enhancing valuable landscape elements. These projects serve as specific experimental laboratories for future urban transformations on a macro scale.

Kellert and Wilson developed a method to study the built environment and formulated the dimensions, elements, and attributes of biophilic design [41]. One dimension, termed organic/naturalistic, relates to a spatial form in the built environment. It is defined as the human affinity with nature. The other dimension is place-based/vernacular. Six elements and seventy characteristics of biophilic design are further subdivided [41]. Apart from the fact that the form can take on a biophilic character, the atmosphere, the process, and the actual impact on the experience are also important.

Browning refers precisely to the criteria of biophilicity. They are presented in the categories nature in space, analogies to nature, and nature of space, and are developed in 14 points: visual connections with nature; non-visual connections with nature; biomorphic forms \& patterns; non-rhythmic sensory stimuli; variability of temperature and airflow; the presence of water; the presence of water; connection with natural systems; material relationship with nature; complexity and order; view; shelter; mystery/mysteriousness; risk/hazard elements [42].

Kellert and Calabrese identified five principles of biophilic design [43]:

- The requirement of repeated and sustained engagements with nature;

- The concentration on human adaptations to the natural world that, over evolutionary time, have advanced people's health, fitness and wellbeing;

- The encouragement of an emotional attachment to particular settings and places;

- The promotion of positive interactions between people and nature that encourage an expanded sense of relationship and responsibility for the human and natural communities;

- The encouragement of mutually reinforcing, interconnected, and integrated architecture. Concerning urban design, the last point directly relates to visual objects.

Tim Beatley, when adopting the principles of Biophilic Design, notes that "biophilic cities are cities of abundant nature in close proximity to large numbers of urbanites; biophilic 
cities are biodiverse cities that value, protect and actively restore this biodiversity; biophilic cities are green and growing cities, organic and natureful" [38].

Beatley $[38,39,44]$ selected the following blocks of biofilm aspects relevant to urban functioning: biophilic conditions and infrastructure; biophilic behaviors, patterns, practices, lifestyles; biophilic attitudes and knowledge; and biophilic institutions and governance. The first block contains spatial attributes, or indicators indicating a relationship with biophilicity: the percentage of the population within a few hundred feet or meters of a park or greenspace; the percentage of a city's land area covered by trees or other vegetation-the number of green design features (e.g., green rooftops, green walls, rain gardens); the extent of natural images, shapes, and forms employed in architecture and seen in the city; the extent of flora and fauna (e.g., species) found within the city.

Referring to specific elements, Beatley divided, according to scale (from building scale to region), as follows [39]: green rooftops, sky gardens and green atria, rooftop gardens, green walls, daylight interior spaces, green courtyards, clustered housing around green areas, native species yards and spaces, green streets, urban trees, and low-impact developments (LID); vegetated swales and skinny streets, edible landscaping, high degrees of permeability, stream daylighting, stream restorations, urban forests, ecology parks, community gardens, neighborhood parks/pocket parks, greening greyfields and brownfields, urban creeks and riparian areas, urban ecological networks, green schools, city tree canopy, community forest/community orchards, greening utility corridors, river systems/floodplains, riparian systems, regional greenspace systems, and the greening of major transport corridors.

According to Tabb [45], biophilic urbanism is a discussion about the desirability of incorporating nature into the physical characteristics of the city and buildings. The biophilic design process is determined by the following attributes: a climate-friendly, healthy, sustainable environment; a commitment to nature; the responsible use of resources; and planning in accordance with climatic conditions and local ecological processes.

Designs embodying biophilic intentions are: nature-based patterns, element-based pat-terns, form-based patterns, place-based patterns, and numinous-based patterns [45].

Andreucci et al. [46] divided biophilic forms according to the scales of building, district, and city. The authors point out the discrepancies between biophilic designs, urban designs, and designs in terms of health needs. They explain this, usually, by the lack of coordination in the interdisciplinary process. The link between urban design and biophilic design fills this gap. The relationship between urbanism and biophilia was coined by Amat et al. between the frameworks: ecological features (natural resources that define the space); existing infrastructure (built environment); and the function of the place [47].

In the case studies, Andreucci et al. cite various examples of applying the biophilic design paradigm. In the Greenwich Millennium Village project (London), the following features can be pointed out: the protection and basic restoration of wildlife habitats (The Ecology Park), the use of wood as a building material, a high greening index, the humanfriendly scale of the place, the occurrence of susceptibility to seasonal variation, etc. In this case, it was the architect Ralph Erskin's idea, and in the case of other projects, the result of a combination of design guidelines and individual decisions [46].

In the case of urban biophilic design, the essence is the connection of everyday life with nature and experiencing nature.

An interesting and different approach to typology in biophilicity is presented by Lee and Park, who make a division according to the effects of impact: health (physical, physiological, psychological), economic (health care costs, energy consumption, excavation costs, profits, and economic impact obtained from regeneration) and social (the strengthening of social ties and the reduction of weaknesses related to the urban character of the place). They propose specific strategies, or a catalogue of actions, that can be applied at three scales: building, unit, and complex [48].

A broad framing and review of urban biophilic criteria was done by Lee and Kim [49]. 
This biophilic design framework can be used as a guideline for new projects, as a conscious design strategy, or as criteria for evaluating already-established areas with these characteristics.

The target function, a university campus or school, obliges using the best development models. They are intended to support the development of users and be an expression of the achievements of science and culture-spirit and time. Additionally, in the case of university areas, solutions of an exceptionally high standard are expected to meet the life-quality conditions according to the criteria of physical health, mental well-being, social conditions, and environmental comfort [37,50-53].

In the case of restructuring areas that undergo radical changes, the issue of place identity and, in particular, a reference to the past arises. Currently, whether national or local, historical identities are increasingly being replaced by the continental or global perspective on identity, i.e., by universal references [54].

History should not be seen as the only explanation to the concept of place identity, as the heritage by which it is shaped includes a range of components, such as environmental potential or the native culture of the place.

Although the effects of changes in biophilic designs are well-known and well-described, it is interesting to deepen our understanding of their source concerning specific realignments. To what extent is the biophilic form the result of environmental analyses? Is it a creative invention, or an aesthetic concept? How does this application transform into a coherent shaping of the development and its surroundings at the scales of city, urban unit, and site?

\section{Methodology}

The example of the transformation of a former paper mill in Nanterre was used as a case study to investigate the impact of process and environmental determinants and others on a biophilic form.

A case study method was applied to a multifaceted example in which knowledge comes from multiple data sources. It is explanatory, descriptive, and partly exploratory in nature. The detailed data was triangulated against general, theoretical knowledge. Analytical generalizations were used in the study of specific issues [55-58]. The purpose of choosing this method was to confirm the biophilic nature of the new development and, above all, to explore the reasons which contributed to such design decisions.

The former paper mill conversion area of 19 hectares is located in the northern part of Nanterre, near Paris, in the République district, between the streets Rue Gutenberg, Avenue de la Commune de Paris, and Rue de Bezons, adjacent to the Seine valley. There is the northern part of Nanterre, on the extension of the Historical Axis of Paris, approximately $4.5 \mathrm{~km}$ from the historic city center. In the vicinity towards the north-west, the Parc du Chemin de l'Île from 2006 and the Seine valley are located, whereas to the north-east, there is the city prison. A little further, the pitch used by students of the Universite Paris Nanterre is located, whereas the main campus area, cut off by the A86 motorway, is found to the southeast of the paper mill area. Towards the southwest of the mill, there are residential areas and military barracks behind the A14 motorway and the railway line (Figure 3).

The paper mill was established in 1904 by Jean Dupuy, who owned "Le Petit Parisien", the daily newspaper (in the circulation of approximately 1 million copies in 1900). The site has played an essential role in the city's history [59]. The object presents a rather typical location for this type of function because river transport was often used for industrial purposes.

The plant was in operation until 2008, with very little activity or production since 1980, like many such facilities. Maintaining the post-production area in the city center in a relatively attractive landscape area on the Seine ceased to be rational, mainly for economic reasons. In 2008, it was decided that the paper mill site would undergo a transformation, initially with no specific use profile. 


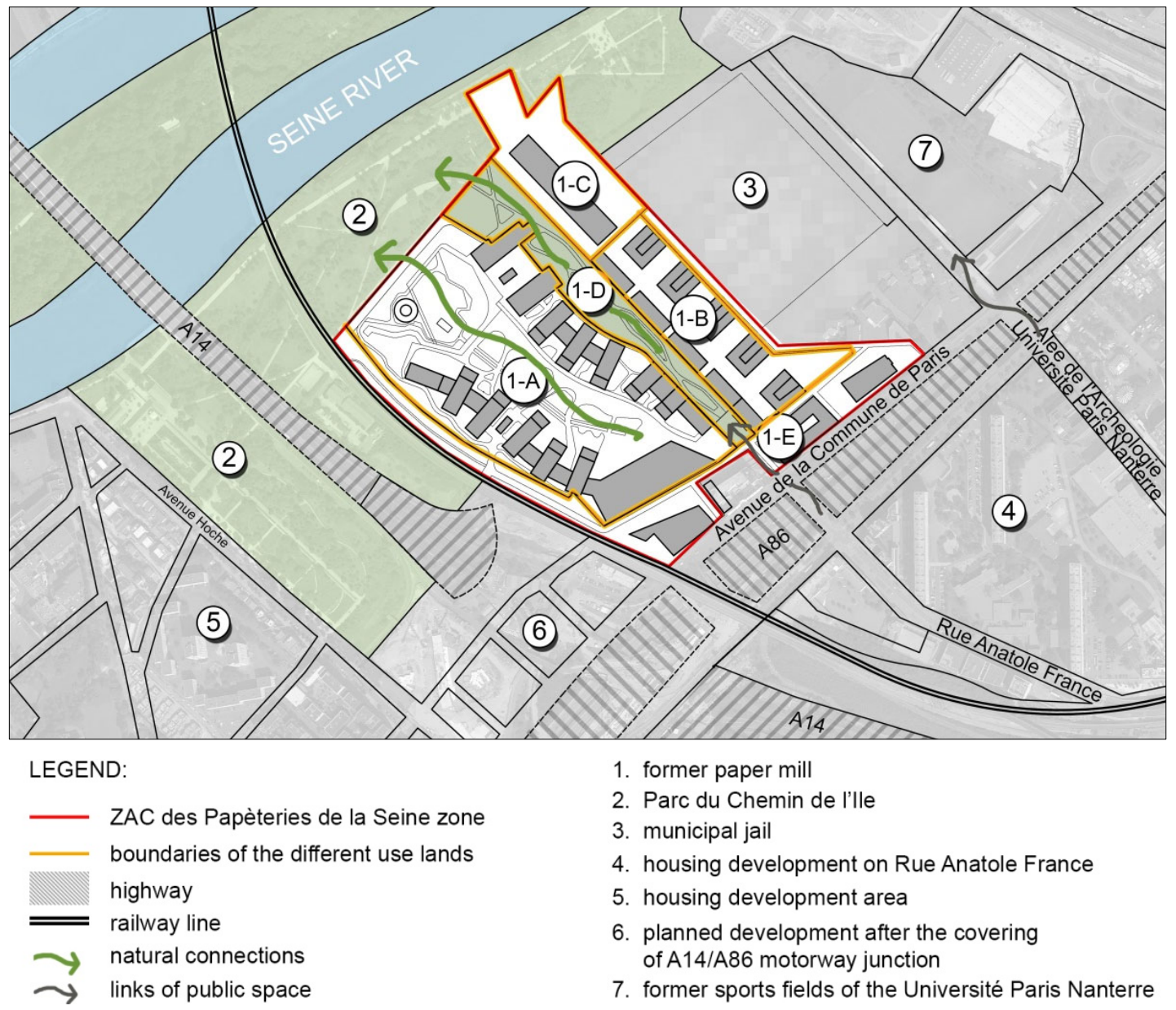

Figure 3. Design concept, together with the surroundings.

The former paper mill in Nanterre was selected for a case study as an example of an area that meets the following criteria: a post-industrial wasteland destined for reuse, a multi-problem area, an area that underwent a transformation process in the last decade. In addition, several feasibility studies have been carried out for the current area using different approaches. An innovative approach was required to introduce the proposed dominant function, i.e., the university campus. The approach may be seen as referential in terms of the scope of the pro-environmental challenges undertaken. The reuse of post-industrial wastelands constitutes a sustainable action with which suburban sprawl is limited. In the case of this type of land, it is necessary to perform decontamination and implement other measures by which the site may be adapted for reuse.

The query of sources concerning the subject matter and place covered the following materials:

- formal and legal (legislative) documents;

- $\quad$ sources directly related to the place: archives, planning materials, expert (opinions, reports, and expert opinions), iconography;

- design materials;

- public information (including the local law);

- $\quad$ elements of journalism (as part of the discourse);

- $\quad$ scientific source literature related to the described issues-broadly understood sustainable city development.

Based on this part of the research, the initial context of the place (its history and significance) was presented. Moreover, a description of the transformation process of the area was prepared; the chronology of the main stages and the current state scope 
were established, the scope of planning arrangements was identified; critical points were recognized; experimental design concepts were reviewed; the final project proposal and assumptions were established.

A comparative analysis of solutions presented at various stages of the investment process constituted a vital part of the present research. Such a study showed the project evaluation as a result of subsequent environmental analyzes performed after 2017.

As the next stage, groups of problem issues (A-G) with a significant impact on decisions and design solutions were distinguished. These include:

- A. Ideological concepts in city planning and formal conditions resulting from regional and local development plans;

- B. Urban conditions resulting from the built environment;

- C. The importance of history and heritage;

- D. The influence of the physical environment on the formation of the concept for the development complex;

- E. Landscape protection and shaping; the influence of the natural environment on decisions;

- F. The influence of social and economic conditions;

- G. Actions against anthropopressure and factors that lead to urban environmental degradation.

Design solutions were divided into four groups (mainly according to the scale impact criterion): I—urban solutions—relations with the city; II—urban and architectural solutions - the scale of the ZAC des Papèteries de la Seine zone; III-architecture and landscape architecture, green infrastructure; IV—the implementation process. These issues have been divided into a total of 21 design aspects. A slightly different division was made by Beatley and Newman [39], based on the study by Girling and Ronald [60]. In these studies, the processual aspect is overlooked, although various scales were analyzed.

Groups of problem issues were juxtaposed with groups of solutions in order to investigate the scope of the influence exerted by the given conditions on the project in the result section. Moreover, in this way, an attempt was made to determine the share of the natural environment elements as the decisive design solution factors. The assessment is quantitative (number of factors) and qualitative (the impact is marked by gradation).

Table 1 presents the general model of post-industrial wasteland transformation and the directions of actions taken during the transformation process.

Table 1. Model for urban wasteland transformation as a part of sustainable development.

\begin{tabular}{|c|c|c|}
\hline State Before the Change & $\begin{array}{l}\text { The Main Trends to Set the Directions of Activities } \\
\text { Focused on the Environment }\end{array}$ & Target State \\
\hline $\begin{array}{l}\text { Degraded areas } \\
\text { Post-industrial areas } \\
\text { Urban wastelands }\end{array}$ & $\begin{array}{l}\text { using wastelands for re-management in the name of the } \\
\text { compact city concept; } \\
\text { adaptation to climate change; } \\
\text { protection of biodiversity; } \\
\text { restoration of ecosystems; } \\
\text { including the environment in pro-health programs; } \\
\text { certification; } \\
\text { procedures; } \\
\text { legislation; } \\
\text { including the stage of the transformation process } \\
\text { (construction) in pro-environmental activities; } \\
\text { design solutions focused on a zero-emission operation } \\
\text { (waste, communication, renewable energy sources). }\end{array}$ & $\begin{array}{l}\text { Biophilic areas } \\
\text { an environmentally friendly city } \\
\text { sustainable city }\end{array}$ \\
\hline
\end{tabular}

In the final stage, the biophilic nature of the transformation project was assessed according to the criteria proposed by Browning et al. [42]. 
In the synthesis of the results, a model of issues was presented. It can be applied as a universal method to develop design and planning concepts, with the account to environmental issues, and to evaluate them. With regards to the scale of impact, solutions can be divided into urban-planning — urban, i.e., those related to a broader context; architectural and urban-planning, i.e., those relating to the layout (composition, space organization, zoning, scale of development) and architectural (form of architecture, selection of materials, and technologies).

\section{Process of Urban Transformation}

The decision-making process concerning the design of the urban-planning layout and functions required an extensive environmental analysis phase. This was due to the complex environmental conditions resulting from the form of activity and infrastructural limitations. Another factor is that the area is characterized by a high environmental sensitivity and a high natural potential (typical for riverside areas). No such large and thorough surveys were carried out for previous feasibility studies. The emphasis on environmental issues stemmed from the investment process and the eventual creation of the urban development zone-Zone d'Aménagement Concerté des Papèteries de la Seine (ZAC des Papèteries de la Seine).

Since April 2008, efforts have been made to include the site of the former plant within the Deferred Development Zone (ZAD_Zone d'Aménagement Différé). In 2010, the municipality of Nanterre granted this status for six years, with the possibility of a onetime extension. The pre-emption right was granted to the municipal company EPADESA (Établissement Public d'Aménagement de La Défense Seine Arche), which manages the La Défense Seine-Arche project. Officially, the factory ceased operations in March 2011. Since then, it has constituted an urban wasteland cut off by transport infrastructure, that is, by railway lines, the A14 and A86 motorways, a detention area, and the Rathelot barracks.

From 2008-2015, this area was repeatedly subject to feasibility studies as design analyses were conducted on behalf of further development. Based on this study, for formal (planning) and environmental reasons, the proposal to transform the area into housing functions was rejected. Ultimately, in 2014, EPADESA refused to start building the ZAC area and rejected its pre-emptive right to the site. Similarly, in 2015, the commune rejected this option.

Following another land ownership change in August 2015, a land development project was commissioned with a logistics center and an economic activity program (arch. François Leclercq). These attempts were aimed at developing a new management method by the new investor in cooperation with public partners: the municipality of Nanterre, the public development company SPLAN (Société Publique Locale d'Aménagement de la Ville de Nanterre), the authorities of the Paris-Ouest La Défense metropolis, the council of the department Hauts-de-Seine, the EPADESA company, prefecture of the Hauts-de-Seine region. The initial framework project was created in 2016 as a necessary element to apply for the creation of the ZAC zone.

The procedure for establishing the ZAC zone at the request of the SPLAN company was launched in March 2016. The required public consultation took place in the same year. In December 2016, the environmental documentation was submitted and approved. In February 2017, the Regional Office for Environmental Protection (MRAe-Missions régionales d'autorité environnementale) issued an opinion with a recommendation to conduct additional environmental studies. In March 2017, a procedure was initiated to verify the compliance of the program assumptions with the commune's urban plan (PLU de Nanterre-Plan Local Urbanisme de Nanterre). It was then necessary to further transform the ZAD des Papèteries zone by ceasing its production. The ZAC des Papèteries de la Seine zone was established in May 2017. In the second half of 2017, the activities to amend the provisions of the PLU plan were initiated so that the plan was compatible with the investment plans. The plan was supplemented with functional and spatial guidelines of 
the OAP (Orientation d'Aménagement et de Programmation) for the zone, including the junction of the A14/A86 motorways, apart from the paper mill and its surroundings.

The choice of the ZAC procedure influenced the scope of the analyses and the extension of public participation in forming the urban concept.

The following were included in the ZAC area: the former paper mill with its building development (approximately $17 \mathrm{ha}$ ), wastelands in the Parc du Chemin de l'Île, the public utility administrative building (Direction Départementale des Territoires), and about ten other facilities - 19 ha in total. The investment commencement was possible only on the condition that the owner acquired additional plots of land (an area of 3,283 $\mathrm{m}^{2}$ ), partly covering Rue de Bezons and the area between that street and Avenue de la Commune de Paris. For this reason, the procedure for removing these sites from the public domain was conducted. The ownership changes affected the organization of traffic. The permit to commence works was issued in 2018 [61] and updated in 2020 [62].

\section{A Case Study of the Urban Development Zone-Zone d'Aménagement Concerté des Papèteries de la Seine (ZAC des Papèteries de la Seine)}

The process of transforming the former paper mill has concerned many aspects typical of this type of project. They have been analyzed in individual subsections. It was important to capture all the aspects (formal and directly resulting from the site) to bring out those that had a real impact on the form of the designed object.

\subsection{Formal Conditions Resulting from Urban Plans $(A)$}

3.1.1. Arrangements Resulting from the Plans: Regional and Local Arrangements for the Former Paper Mill Area

The following general postulates are contained in the main assumptions of the plan for the Île-de-France region (Le Schéma directeur de la région Île-de-France-SDRiF), 2013: the preservation of open spaces and landscapes, the optimization of urban transport logistics, the reduction of risk and environmental arduousness, and the reduction of greenhouse gas emissions [63].

At the time of establishing the ZAC des Papeteries zone, the 2015 local Nanterre plan was in force (Plan Local d'Urbanisme de la Commune de Nanterre-PLU de Nanterre) [64]. It was amended several times-also for the area in question between 2017 and 2021 [65]. In 2017, functional and spatial guidelines (OAP-Orientation d'Aménagement et de Programmation) for the A14/A86 motorway junction zone and the paper mill area was introduced in the plan.

The 2015 plan assumed the following goals: creating an intermodal logistics platform aimed at reducing car traffic; the development of the economic function in the area; introducing innovative investments to promote knowledge and technology; improving access to the river and the park; and the preservation of particular historical objects as an expression of time continuity.

Overall long-term goals in the field of sustainable planning and development were set in the local plan for Nanterre (Projet d'Aménagement et de Dévelopement DurablePADD). These goals included the postulate of a city that is friendly to living and working. Attention was paid to the role of the city in the energy transformation, as the area should act for the benefit of the environment and inhabitants. The importance of Nanterre was determined as a city that supports the development of the metropolis. The need for changes in the scope of traffic was indicated [64]. The target locations of the economic function and the green transport function were indicated within the former paper mill area. The area was placed in the so-called green and blue ecological zones, for which the existing ecological connections should be maintained and new ones should be introduced. The emphasis on the area's connection with the Seine was the main objective. The plan also points to the great importance of the neighboring Parc du Chemin de l'Ile to preserve biodiversity.

In the functional and spatial guidelines (Orientation d'Aménagement et de Programmation-OAP) prepared as part of the local plan, detailed development rules 
were established for the paper mill area and its surroundings. These included the following issues: workplace diversity, the protection of residence places against arduous roads (mainly noise from highways), the urban tissue continuity, the quality and cohesion of public space, urban and landscape quality, and the principles of ecological, economic, and housing development [65]. Detailed arrangements covered several dozen indications, the most important of which were as follows: limiting office space to $145,000 \mathrm{~m}^{2}$, covering the A14/A86 motorway junction, ensuring public space availability, connection with the Seine valley and the Parc du Chemin de l'Ile park, the extension of Rue Anatole France, and the preservation of the Historical Axis of Paris viewpoint.

Changes in the formation of functional zones in the plans for 2015 and 2021 are presented in Figure 4, whereas the development parameters are compared in Table 2.
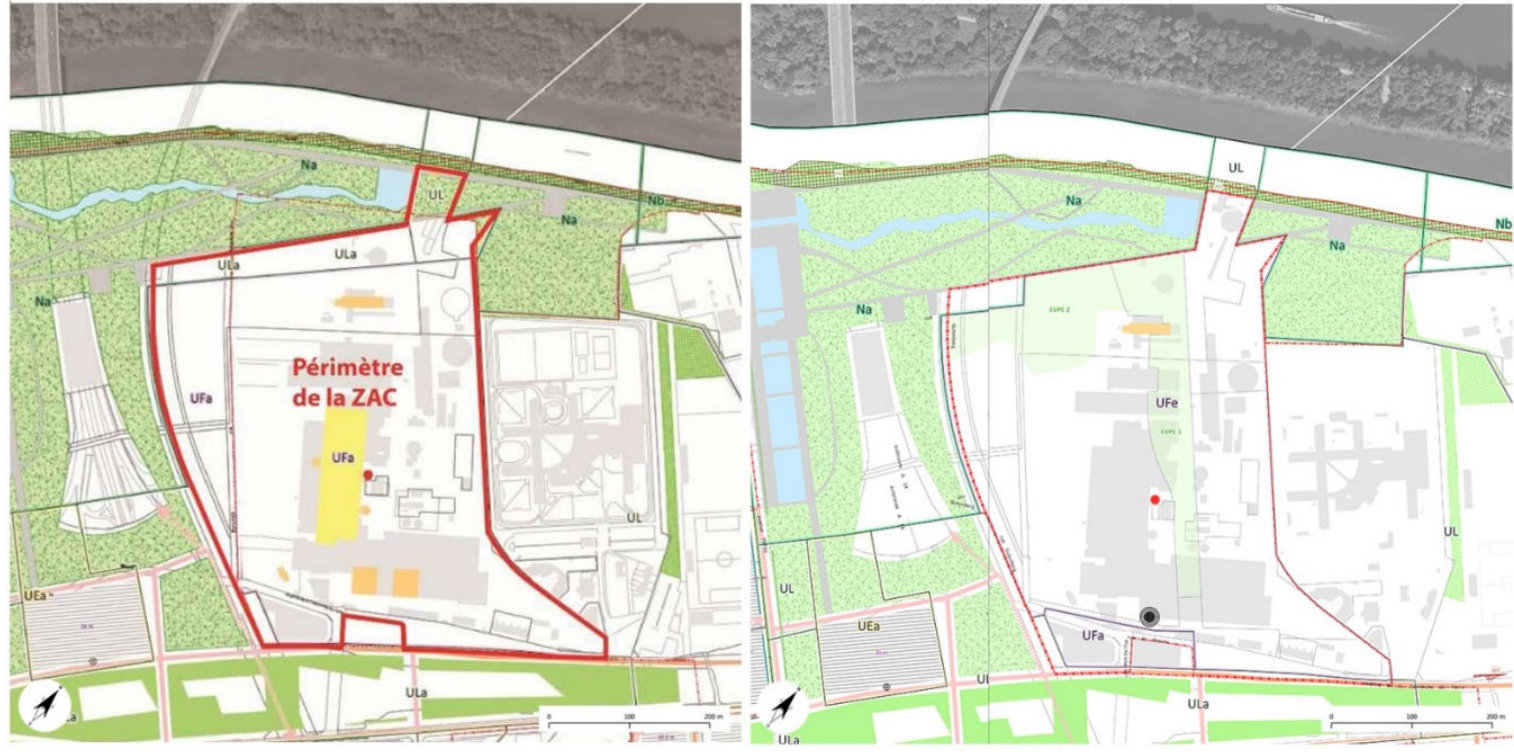

Legend:

ZAC des Papèteries de la Seine zone

EVPC - green areas protection area (also for new areas);

UFa - an economic sector dominated by industry, crafts, and warehouses; commercial space and offices are limited; UFe - mixed business sector with lots of vegetation;

ULa - landscape area, sparsely built-up: spaces intended for sports, relaxation, or recreation;

UL - zone for large facilities of public importance;

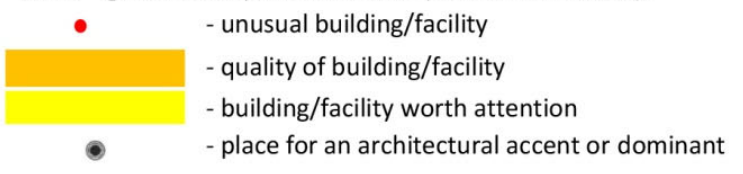

Figure 4. Part of the 2015 Nanterre urban plan at the examining stage on the compatibility of investment provisions [64] and the plan after the changes (as of 2021) [65].

Changes in building development parameters were introduced and related arrangements were made. This allowed for building development concentration in the Avenue de la Commune de Paris zone. Thus, a more effective use of areas with less natural values was ensured. Such a location of the development was possible, owing to the partial covering of the A86 motorway. The new arrangements comprised the protection of grasslands and a ban on development thereof in the rest of the plot. Comparing these two provisions (Table 2), it can be concluded that greater development possibilities have been obtained while ensuring more effective environmental conditions. 
Table 2. Comparison of the change in the share of built-up and open areas in plans from 2015 [64] and 2021 [65]. Table by authors.

\begin{tabular}{|c|c|c|c|c|c|}
\hline & \multicolumn{3}{|c|}{2015} & \multicolumn{2}{|l|}{2021} \\
\hline & Zone UFa & Zone UL & Zone ULa & $\begin{array}{c}\text { Zone UFe: For the Service Sector } \\
\text { (campus) and PME/PMI Sites and } \\
\text { Logistics Platform }\end{array}$ & Zone Ufa \\
\hline $\begin{array}{l}\text { maximum } \\
\text { building } \\
\text { development } \\
\text { area }\end{array}$ & $70 \%$ & no provisions & no provision & $\begin{array}{l}\text { no restrictions on a } 50-\mathrm{m} \text { wide lane, } \\
\text { calculated from the edge of Avenue de } \\
\text { la Commune de Paris } \\
36 \% \text {-for buildings with an area of } 14 \mathrm{~m} \\
50 \% \text {-for buildings up to } 14 \mathrm{~m} \text { high }\end{array}$ & $70 \%$ \\
\hline $\begin{array}{l}\text { maximum } \\
\text { building } \\
\text { development } \\
\text { height }\end{array}$ & $22 \mathrm{~m}$ & $20 \mathrm{~m}$ & $9 \mathrm{~m}$ & $\begin{array}{c}14 \mathrm{~m} \\
35 \mathrm{~m} \text { - with the possibility of local } \\
\text { elevation to } 44 \mathrm{~m}\end{array}$ & $22 \mathrm{~m}$ \\
\hline $\begin{array}{l}\text { minimum share } \\
\text { of open areas }\end{array}$ & $\begin{array}{c}25 \% \text { of open } \\
\text { spaces within the } \\
\text { site, } \\
\text { i.e., } 7.5 \% \text { of the } \\
\text { plot area }\end{array}$ & $\begin{array}{c}10 \% \text { of the plot } \\
\text { area }\end{array}$ & $\begin{array}{c}60 \% \text { of the plot } \\
\text { area }\end{array}$ & $\begin{array}{c}8 \% \text {-if no buildings are located with an } \\
\text { area of approx. } 14 \mathrm{~m} \\
33 \% \text {-if the object on the site is } 14 \mathrm{~m} \text { in } \\
\text { the height } \\
+ \text { additional obligations towards the } \\
\text { EVP zone } \\
8 \%\end{array}$ & $\begin{array}{l}25 \% \text {, and } 60 \% \text { if the } \\
\text { building is situated } \\
\text { away from the } \\
\text { building } \\
\text { development line }\end{array}$ \\
\hline Greenery & - & - & - & $\begin{array}{c}\text { protection of greenery in EVP areas }+ \\
\text { green terraces or renewable energy } \\
\text { sources on roofs for a minimum of } 70 \% \\
\text { of the roof area }\end{array}$ & $\begin{array}{l}\text { green terraces or } \\
\text { renewable energy } \\
\text { sources on roofs for a } \\
\text { minimum of } 70 \% \text { of } \\
\text { the roof area }\end{array}$ \\
\hline
\end{tabular}

\subsubsection{Land Subdivision}

While comparing the ownership division as of 2015 and 2021, it stems from this that it was necessary to introduce secondary land subdivisions with which to separate the future park areas and communication areas from the Avenue de la Commune de Paris side. Together with a uniform ownership structure, large plots of land provided relatively good initial conditions for the functional zone development (Figure 5).
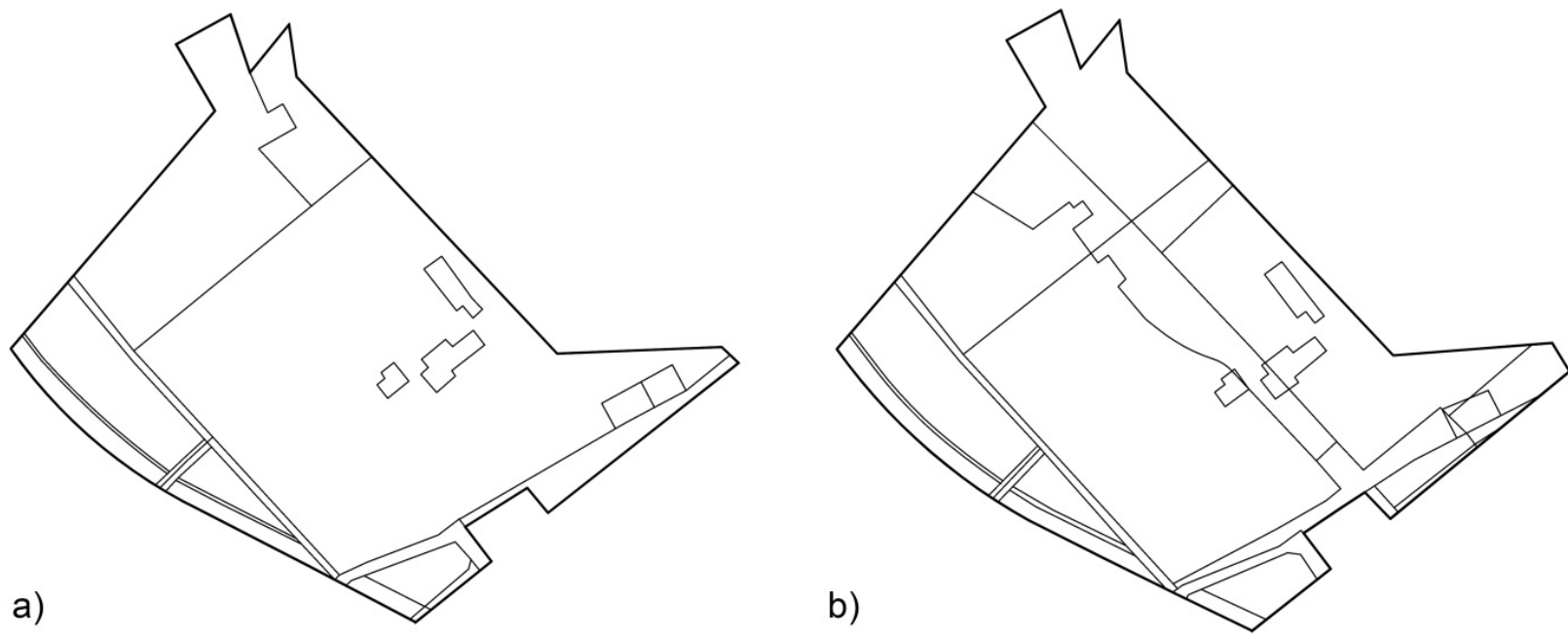

Figure 5. Land subdivision in 2015 (a) and 2021 (b).

\subsubsection{Functional-Spatial Program}

The functional program has evolved since the creation of the ZAC. Eventually, a permission was granted for the development with the following functional division [62]: zone A-a campsite with a greenery area-an arboretum (usable area: $127,800 \mathrm{~m}^{2}$ ); zone $\mathrm{B}$ - a business park with small- and medium-sized enterprises (usable area: 25,000 $\mathrm{m}^{2}$ ); zone C-river logistic platform (usable area: 10,000-15,000 $\mathrm{m}^{2}$ ); zone E—shops and services 
(usable area: $5000 \mathrm{~m}^{2}$ ); zone E4—new mosque (usable area: $2922 \mathrm{~m}^{2}$ ). Zone D, with an area of 1.99 ha, was allocated to the expansion of the Parc du Chemin de l'Ile. As part of the entire area, 2030 parking slots are planned in the underground storeys and in the car park building (with the possibility of changing the function in the future). The area's division into functional zones is presented in Figure 3. The landscape relations are presented in Figure 6.

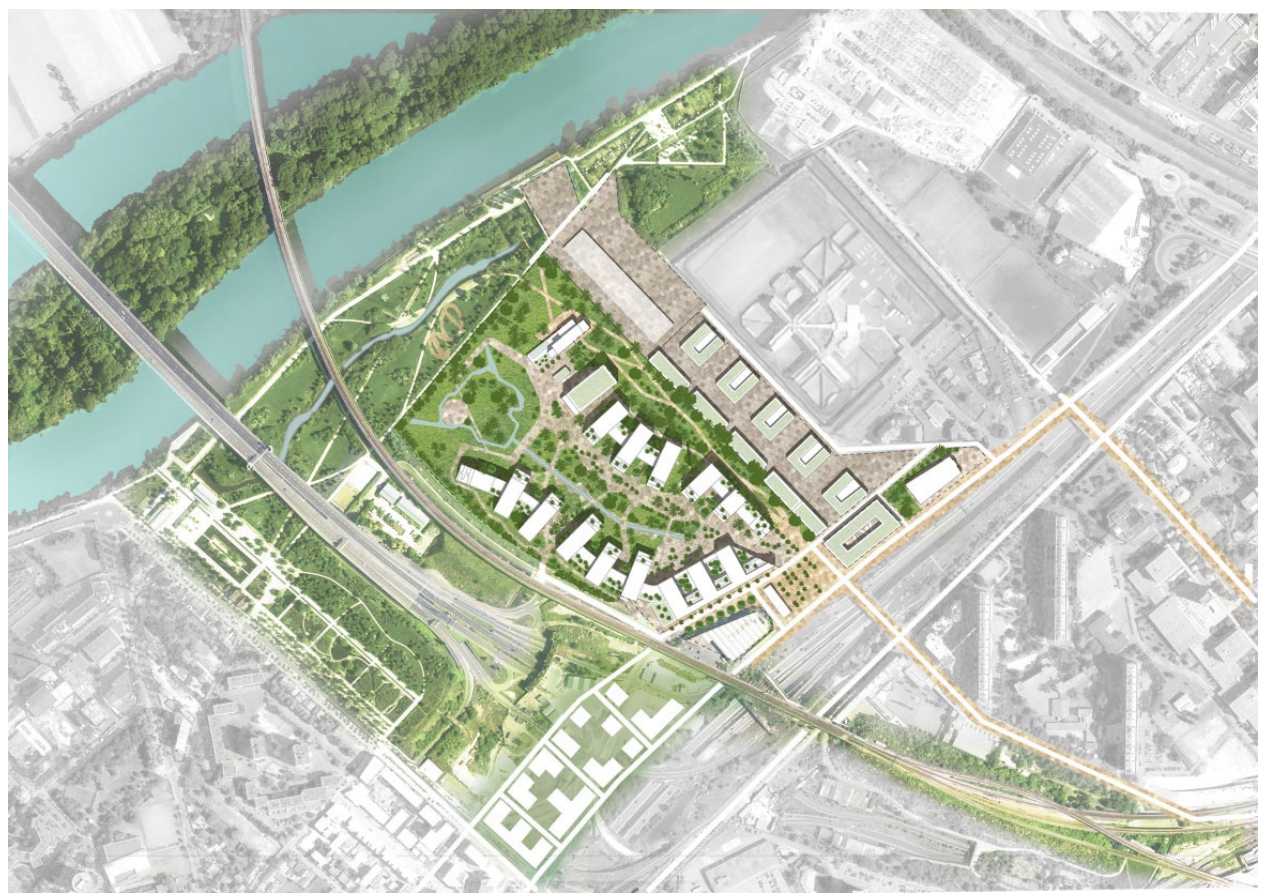

Figure 6. Land development project (source: Leclercq Associés; Leclercq Associés; Laisné—DREAM, BASE).

\subsection{Urban and Built Environment Conditions (B)}

\subsubsection{Location of the Area within the City Structure}

The former paper mill site is situated at the extension of the Historical Axis of Paris, i.e., the axis marking urban structures of significance to Paris' history, built since the 17 th century.

The Seine coastal strip is primarily developed with post-industrial storage and warehousing sites, currently under a large-scale urban transformation. The former paper mill site is located in the land quarter cut off by the A14 and A86 motorways and railway lines, which created conditions for unfavorable isolation of the area from the city structure.

The proximity of the Chemin de l'Ile park and the University of Nanterre campus allowed mutual connections to be formed. Several spatial barriers had existed in the area. This situation called for action to integrate the space into the city structure and integrate the area with the river through green connections and communication routes. The elimination of the existing barriers and obstacles to communication was also crucial. These conditions mainly influenced the communication system, as well as the creation of public spaces and the functional zoning in the transformation areas.

\subsubsection{Urban Layout Characteristics}

The former paper mill layout was subject to the production function. No structure of public spaces was present, apart from the entrance area and the administration building, as well as a wide access path along with the paper warehouses in the entrance area (Figure 7). In the new layout, the entrance zone has been shifted to the northeast. This was determined by the extension of Rue Anatole France. A part of the former road that connected the pumping station and the maintenance workshop has become part of the park extension 
area. The boundaries of the former paper mill delineated the area of the new architectural, landscape, and architectural complex.

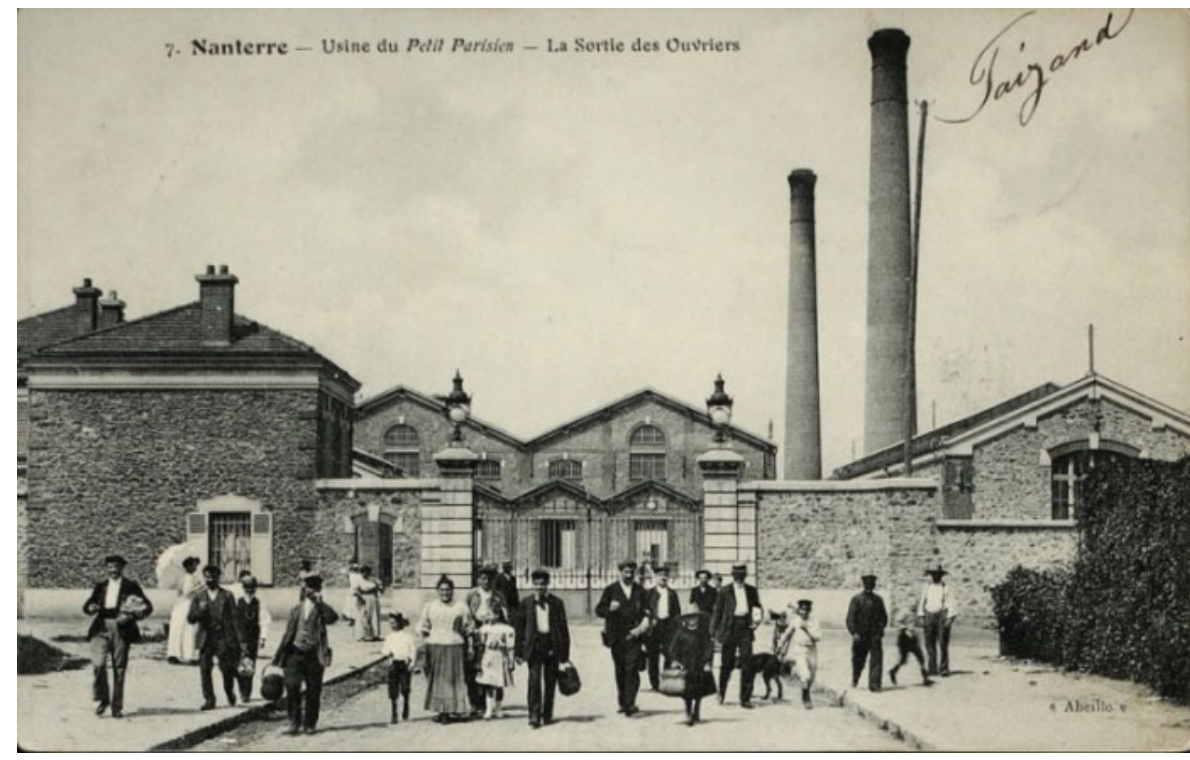

Figure 7. Entrance to the paper mill premises - visible chimneys characteristic of the landscapeview from around 1911 (the first chimney was demolished in 1982, the second one in 2020). (Source: Archives départementales des Hauts-de-Seine; CC BY-NC-SA 2.0 FR).

The individual objects, as well as the complex, provided a research topic in terms of historical heritage.

\subsection{The Importance of History and Heritage (C)}

Since the 1960s-1970s, an increase in the importance of protection was noticed, especially regarding monument complexes being building complexes. A historical heritage became an essential factor in spatial planning [66]. Industrial heritage arises as a relatively new type of heritage [67-69]. Although its value is widely recognized, the transformation of post-industrial areas still results in the disappearance of factories and plants. These objects, however, offer a material testimony of importance to the functioning of cities and constitute an explicit element of the urban landscape [70].

The site of the paper mill does not lie within the influence of the monuments. On the other hand, the area's location on the extension of the Historical Axis of Paris has historical potential, as the feature determines the structural system and connections.

\subsubsection{Valorization of Facilities on the Former Paper Mill Premises}

The former paper mill buildings were under no legal protection. The majority of construction was erected in the initial period of the plant's operation-i.e., in 1900-1920 and in the 1940s. The system was characterized by the rationality typical of industrial facilities; it was subordinated to a specific production. The layout consisted of production buildings, warehouses, power-generating facilities, and conservation workshops. Subsequent extensions and demolitions, as well as transformations, followed the evolving production process, the change of the raw materials used, and the required energy sources. The buildings were then connected by the Number 60 railway line, with a branch of the Paris-Le Havre line. The production function determined the shaping of the urban layout at that time.

In the local urban development plan of 2015 [64], several former paper mill objects were considered valuable and recommended for preservation. Ultimately, however, it was decided in the design prepared for establishing the ZAC zone to retain three buildings as evidence of architectural heritage and the place identity. The choice was made via 
social consultations and agreements with the historian community before creating the ZAC zone [71]. One of the industrial buildings in the western part of the complex, in which the technology to process wheat straw into pulp ('Pâte à paille') had been developed, was recognized as a high-quality facility intended for revitalization. The second building-the so-called grinding mill ("Trituration") had previously been used to obtain cellulose by crushing wood logs. In its vicinity, industrial cranes have also been preserved. Both objects date back to the 1930s and 1940s. In addition, attention was drawn to the chimney, i.e., the dominant element in the former industrial landscape. It was included in the urban plan as an "exceptional object", but, in 2020, it was demolished due to the technical condition of its foundations.

\subsubsection{Assessment of the Preservation of Past Elements in the Project}

It was decided that these buildings are modernized and adapted to sports and gastronomic functions. In the first building, a fitness center (LA Fabrique) was proposed, whereas, in the second one, a restaurant was planned to benefit from local supplies and crops. Due to poor technical conditions, it was eventually decided to demolish the remaining objects. Moreover, the decision was prompted by the functional-spatial requirements of the area's transformation, as well as the requirements of changing the site into a high environmental quality area.

The intangible elements of heritage include the complex nature of the building development, the area's boundaries, and the use of the Seine for river transport. The area's cultural significance, so far, originated from its development. Therefore, the protection of the past values of the place became essential for its space-time continuity. The materials obtained from demolishing buildings were partly intended for reuse in landscape projects-e.g., paving stones, bricks, or tall cranes visible in the distance.

Traces of material remnants in the new development are reminiscent of the plant's importance for the economic development of Nanterre. None of the objects have been protected as monuments. The history is documented by the departmental archive, including the heritage documentation associated with the factory real estate. Both industrial buildings and workers' housing are described therein. Archive resources include the documentation of buildings and land (documents, registers, contracts, property, appraisals, approvals, and inventories); industrial infrastructure (documentation related to production); production inventories; and insurance for particular years and plans [72]. Archaeological research is planned before construction work to verify the existence of potential archaeological heritage elements [61].

\subsection{The Influence of the Physical Environment on the Formation of the Building Development Complex Concept (D)}

\subsubsection{Climate}

Global climate changes require adaptation to make cities more resilient. [73]. Adaptation activities exert a significant impact on such factors as shaping the architectural form, location, layout, and size of functional zones, the orientation of buildings, the choice of materials, the energy sources applied, the use of passive low-energy solutions, shaping greenery zones with water, the construction process, and on programming the building's lifecycle $[74,75]$.

By strengthening the existing city structure, the new development of the post-industrial wasteland counteracts urban sprawl, as well as limits the need for expanding transportation networks to serve distant city parts. In terms of climatic conditions, a great emphasis was placed on sustainable land development and low-emission solutions in the design concept.

The previously existing type of development (hall buildings and concrete-covered surfaces) was characterized by a large extent of area sealing, over $70 \%$ of the total area, which contributed to the emergence of heat islands. In the new layout, biologically active and mineral areas with tree-covered fields and surface waters cover over 10.6 ha (approx. $55 \%$ ), which positively affects the microclimate of the entire site [71]. These elements 
shape the place's topoclimate and determine the user's thermal comfort while limiting the occurrence of the urban heat islands phenomenon [76-79]. The green and blue network areas (TVB - La Trame verte et bleue) play an ecological, landscape, and social role and regulate water management. This is especially important in the vicinity of residential areas. The densification of urban areas usually raises the local temperature. The mitigation of these effects can be achieved by introducing vegetation, especially trees, water areas, and paving and roofing materials with the highest albedo coefficient and an appropriate urban form conducive to the area's ventilation.

With the right choice of building materials, $\mathrm{CO}_{2}$ emissions can be significantly reduced The use of local and locally recycled materials reduces construction deliveries via road transport [80]. It is assumed that buildings provide for $50-60 \%$ of the carbon footprint (originating from building materials and operation), whereas the construction waste itself accounts for over $50 \%$ of all waste [81]. In the case of this design, cross-laminated timber (CLT-Cross Laminated Timber system) and laminated timber (LVL_-Laminated Veneer Lumber system) with formaldehyde-free adhesives were proposed as the primary building material for the campus facilities (an area of $8.9 \mathrm{ha}$ ). Wood is used as a renewable material with a low carbon footprint. Experimental studies show an energy savings comparison to reinforced concrete objects by almost 30\% [82]. The building material's lightness reduces energy consumption, in terms of its delivery, by up to $50 \%$. A similar reduction in energy consumption results in easy and quick assembly of the ready-made, prefabricated elements [71]. It was assumed that the wood used to build the campus would be imported from Austria, which was accounted for in the energy balance. Research on the use of wood as a building material confirms its ecological properties. Still, this feature depends on the wood mixtures, where it was obtained, and the distribution of sawmills. Locally obtained timber can increase the Global Warming Potential indicator (GWP) effectiveness by $14 \%[83]$.

As part of the low-emission operation of the campus buildings, the use of renewable energy sources, i.e., geothermal energy and photovoltaics, was intended. It has been estimated that geothermal sources will provide for $75 \%$ of the heating energy demand and $50 \%$ of the ventilation energy demand. Photovoltaic panels $\left(1750 \mathrm{~m}^{2}\right)$ will provide $700 \mathrm{MWh} /$ year [71], which will constitute $18 \%$ of the campus's energy demand in total [84].

The study on the adaptation of the designed buildings to other functions showed that the office function in two buildings could be replaced with a residential function in a zone safe from noise sources [85]. Thanks to lower raw materials and energy consumption, the future transformation potential is beneficial for the environment [86]. In the field of recycling, it was assumed that concrete would be used (after crumbling and testing its physical properties) for implementation as a road base. The excess debris was to be removed from the investment area.

\subsubsection{Topographic and Geological Conditions}

The project area is located near the Seine valley on a relatively flattened area, $30 \mathrm{~m}$ above sea level. Artificial topography elements comprise embankments related to the course of communication routes. In the course of investment works, the A14/A86 motorways junction was partially covered to mitigate transport-noise sources. This had a slight impact on the topography of the surroundings. In topography shaping, the emphasis was placed on leaving soil masses obtained during the excavations of underground stories on the investment site, and using them for levelling the area after decontamination activities. This is a sustainable development approach [87].

In accordance with the design assumptions, the area was slightly elevated as a result. In order to limit the impact of the construction materials stored for the investment implementation, it was recommended that the construction works be conducted quickly. 


\subsubsection{Subcutaneous and Surface Waters}

The Seine provides the fundamental elements of the area's hydrological system. In the planning documentation, part of the area was classified as class 3 wetlands, that is, areas with a high probability of surface waters requiring an inspection [88]. Physically, the wetland is present only in the form of a small pond in the western part of the site. This factor was used as part of the landscape design in the project. The groundwater condition was recognized as poor in chemical terms due to heavy metals, hydrocarbons, and pesticides [85]. However, this did not affect the drinking water catchment located outside the range of the water impact from this area. During the design works, measures were taken to protect the surface waters and purify the rainwater, e.g., by infiltration, the application of hydrophytic greenery, the elimination or isolation of contamination hazards, the separation of rainwater, and sanitary sewage systems.

The threat to the hydrological system may impact the construction process. The dangers may arise from the organization of the construction site, primarily, various types of building material storage and the operation of machines, both of which may cause the formation of contaminant suspensions. The risk of polluting the Seine's waters results from the river's proximity. The protection of subcutaneous waters consists primarily in the protection of surface waters and soil. The water circulation and water protection issues during the construction process have been specified in the Charter of Ecological Building (Charte Chantier Vert) as one of its objectives [71]. Any construction processes resulting in possible contamination were shortened so as to avoid the runoff of harmful substances into the river valley.

\subsubsection{Flood Threat}

Restrictions in the use of underground stories resulted from the groundwater level and the flooding risk. The initially assumed depth of the excavations was not to exceed the water level noted during the 2016 flooding period. Two underground stories have been designed for the campus buildings.

In the Flood Risk Prevention Plan for the Hauts-de-Seine department (Plan de Prévention des Risques d'Inondation des Hauts-de-Seine-PPRI), the area partially belongs to the orange " $\mathrm{C}$ " zone, which indicated the need to limit the development densification and the use of basements (except for underground car parks). For zone " $\mathrm{C}$ ", the plan includes limiting the construction to $40 \%$ in residential and office functions and $60 \%$ for other functions if the buildings are located on plots bigger than $2500 \mathrm{~m}^{2}$ [89]. In the design opinion, attention was drawn to the high water table, which may result in flooding during heavy rainfall (mainly in the western part of the area). It was recommended that the research be supplemented, and simulations for 10-year, 50-year, and 100-year floods were performed [85]. A study conducted by the specialized BURGEAP office in 2017 showed that in the event of a 50-year flood, the two-storey parking lot might be flooded up to the level of $0.5 \mathrm{~m}$ [85].

In the case of a 100-year flood, water runoff along secondary roads to open greenery areas and towards the Seine was indicated [61]. The existing buildings were demolished in the flood zone, with no disturbance to the area's topography. In this zone, two objects were built (in zones $\mathrm{C}$ and $\mathrm{E} 4$ ), thanks to the designed safety installations. To compensate for the area subtraction in the Seine valley flood zone, the creation of an embankment was proposed. Moreover, the site would be provided with a special flood zone connected to the Seine, for which the water level would be regulated by a floodgate [62].

\subsubsection{Solutions Related to Rainwater Collection}

The rainwater drainage system assumes water retention within the plot, and slows down water runoff so as to ensure a balance in the functioning of the sewage system. In Nanterre, additional retention reservoirs are used to relieve the rainwater drainage system during heavy rainfall. Storm drains that flow into the Seine were introduced in the street network. According to the sanitary plan for the Hauts-de-Seine department (Le schéma 
départemental d'assainissement pour la période 2005-2020), the basic solution consists in rainwater management within the plot [90]. If this is not possible, a permit can be obtained from the sewage system operator to dispose of the rainwater into the public network with a specific throughput value. Pursuant to the regulations, it is forbidden to discharge rainwater into the sanitary system.

At the design stage, it is compulsory to prepare a rainwater management plan [89], which influences biologically active surface zones and the LID (Low-Impact Drainage) solutions. Such a plan consists of using wet ditches, setting up roof gardens, storing rainwater within the inhabitants own plots, and, most importantly, minimizing the use of constricted surfaces to reduce the average rainwater runoff coefficient. These activities belong to the basic sustainable design scope [91-93].

It is assumed in the rainwater management plan that during the investment implementation, water will be collected in a temporary drainage system and then drained and transferred into the ground. In the project, for an area of 19 ha, greenery and mineral (permeable) areas constitute approximately 10.6 ha. Further design assumptions provide for constructing an open reservoir system in zone A and a watertight channel (area 1.2 ha), into which water will flow naturally, whereas the quays will be provided with an infiltrating substrate (area $2725 \mathrm{~m}^{2}$ ). The channel is provided with a safety bolt to cut off the water supply in case of contamination. Rainwater from the roof surfaces will be stored in four underground tanks $\left(125 \mathrm{~m}^{3}\right.$ each) and intended for watering plants in the park. The reservoirs include an overflow system-it will be transferred to the water channel in the event of excess water [62]. Rainwater discharge into the network was not allowed in zones B and D. The water is collected through the ditch located to the north of these zones, whereas the infiltration areas are $1460 \mathrm{~m}^{2}$ and $1580 \mathrm{~m}^{2}$, respectively. Depressions exist in the $\mathrm{D}$ zone (i.e., the park extension zone); thus, almost the entire area is greenery-covered. The whole area serves the infiltration [62]. In some zones, discharge to the rainwater sewage system is allowed on the terms specified by the network operator-e.g., in the E2 and E3 zones. In the E4 zone, rainwater is taken over by the valley extension, whose area totals $1.33 \mathrm{ha}$, to an open retention reservoir for water infiltration [62]. Actions to enable the natural drainage of water to the ground influence the regulation of water circulation and lead to the minimization of the heat island effect [62].

\subsection{Landscape Protection and Shaping; the Impact of the Natural Environment on Design Decisions (E)}

3.5.1. Landscape and Influence on Design Solutions

According to the European Landscape Convention, the landscape is most often defined as a "space perceived by people, containing natural elements or products of civilization, shaped as a result of the action of natural factors or human activity" (translation by the author) [94]. It can also be defined by reference to the nearby characteristic and valuable landscape units, which constitute elements to structure the overall landscape.

The juxtaposition of the studied area with its surroundings, especially if it expresses the landscape continuity of natural areas, is also of ecological significance. The complexes of characteristic and valuable landscape units have been distinguished in the so-called landscape atlas of the Hauts-de-Seine department and included as the "The Seine ring from Rue-il-Malaison to Villeneuve-la-Garenne" [95]. The following elements have a considerable impact on the landscape: the Seine valley and its layout emphasized by tree plantings; diversified and, occasionally, contradictory urban development intersected by the road infrastructure; the area of La Défense constituting a landscape with a strong image and an orientation spot within the space; and in some places, a flat topographic layout and an open landscape with valuable, extensive viewing fields. The Mont-Valérien hill and its slopes dominate the Seine inter-river basin (Les deux Seine). They provide a viewing point from which the vast landscapes at its foot can be observed. The Historical Axis of Paris-an extension of the Seine-Arc (Seine-Arche) section, plays a structuring role [96]. The complex of characteristic landscape units also includes areas distinguished by a functionally and 
spatially coherent layout, e.g., the University of Nanterre area. City fragments undergoing transformations, and the resultant new building developments, blur the readability of the Seine valley and Mont-Valérien hill as the original topographic system. Contrasts emerge in the development of areas, which causes interruptions in the continuity of landscape perception. Thus, its legibility is locally reduced, which makes it challenging to identify the area.

The use of the landscape and natural potential is consistent with the sustainable planning and development project provisions in the local urban-planning plan. It is postulated that natural forms are developed in the city, while the landscape values are applied to consolidate identification and identity elements and strengthen bonds between users [62]. In developing the former paper mill area, the critical action to connect landscapes was to introduce a landscape axis perpendicular to the Seine (extension of the Parc du Chemin de l'Île). Further notable actions included opening the landscape in the western part of the area-from the Seine-and introducing frontage (compact) development forms along Avenue de la Commune de Paris. In the open areas, the potential was used related to vegetation and habitat formation once the production was ceased. The area created in this way totals 4.3 ha. The landscape design was inspired by the vegetation of l'Ile Fleurie, an island on the Seine.

In the natural system of Paris, the following elements are of regional importance: the Seine valley and the Parc du Chemin de l'Île, as these areas constitute ecological corridors. They have been demonstrated in the Regional System of Ecological Cohesion (Schema Regional de Coherence Ecologique-SRCE) [97]. At a distance of $100 \mathrm{~m}$, a special area of ecological importance was located, which is important for flora and fauna (Zone naturelle d'intérêt écolo-gique, faunistique et floristique-ZNIEFF). In the National Inventory of Natural Heritage (L'Inventaire National du Patrimoine Naturel-INPN), it was listed as ZNIEFF 110030012: BERGES DE LA SEINE A NANTERRE-linked to other areas, including areas sensitive in terms of nature (l'Espace Naturel Sensible-ENS) [98].

\subsubsection{Plant and Animal Habitats}

As part of investment activities in the spring of 2015, a partial inventory of flora and fauna was conducted. The survey, completed in 2017, covers the entirety of the ZAC zone, as well as the Seine riverside [99]. Initially, the inventory consisted of three wasteland zones covered with ruderal vegetation. The first two, situated towards the southwestern part of the plot, were characterized by a similar plant cover, i.e., wastelands colonized by tree vegetation. Native species accounted for $14 \%$ of all inventoried plants [99]. The zone adjacent to the railway has been classified as a naturally sensitive area (1'Espace Naturel Sensible-ENS). It has been shown that invasive species constitute a large part of the vegetation in the zone [99]. The third zone is an apparently deserted area. However, the inventory proved that it promotes water vegetation and animals owing to water reservoirs. In the Seine zone, these areas may provide a habitat for willows, which, in turn, may serve as a bat sanctuary [99].

Based on the 2017 inventory, the occurrence of species of rare animals has been revealed. The abandonment of land use resulted in the development of anthropogenic habitats of three bat species in walls and lintel cracks. Protected species present in the area resulted in the obligation to prepare an additional report on the environmental impact assessment. The document was attached to the application for establishing the ZAC zone. In the final assessment, the report indicated the possibilities for improving the habitat conditions of wild bird species, amphibians, and reptiles (e.g., wall lizards (Podarcis muralis) and animals living in railway embankments after the investment's completion. A total of fifty-seven animal species were identified, eighteen of which belong to the natural heritage. Thanks to this research, it was decided to enlarge some areas and to transfer vegetation to the restored areas [85].

In the field of biodiversity protection, the main activity refers to the protection of grasslands and the expansion of green zones and combating invasive vegetation. The 
implementation project assumed the use of ecosystem service elements, i.e., insect hotels and nesting boxes, and arranged places for insects to live (stones, walls, shrubs, storage places for wooden elements). Paths have been delineated in order to isolate some areas and retain them as nature sanctuaries. In terms of fauna protection, it was recommended to indicate whether any bats inhabit the buildings before demolishing them. Works in the modernized "Trituration" building were planned outside the breeding season of the pond bat (Myotis dasycneme). Moreover, it was planned that, after the modernization, bats would be transferred to special nesting boxes. The demolished parts of the walls were considered in the arrangement of green areas for the needs of lizard habitats [61].

According to the plan for the Ile-de-France region (Le Schéma directeur de la région Île-de-France-SDRiF), greenery areas in the Seine-Arche zone should constitute a mutual connections system [63]. The level of greening was negatively affected by the building development densification in the area, as well as by the change in the nature of its development. New buildings have been erected in the main campus area, and the pitch between the campus and the Anatole de la France district has been removed, whereas development is planned along the Avenue de la Republique for the greenery wasteland area.

According to the environmental decision for the area in question, it was ordered to retain the area of $1000 \mathrm{~m}^{2}$ of the existing wastelands. An additional area of $1500 \mathrm{~m}^{2}$ was intended to restore the remaining part to preserve the diversity of species, i.e., to transfer flora and fauna from zones 1 and 2 (e.g., this applies mainly to the habitats of the blue-winged grasshopper (Oedipoda caerulescens)). It was also recommended to create a wetland within the internal green area [85]. The existing $1800 \mathrm{~m}^{2}$ of green wasteland located in the campus zone (zone A) was finally secured. An additional $2000 \mathrm{~m}^{2}$ of the area was subsequently added to the wasteland in the park zone (zone D) [61].

\subsubsection{Special Protection for Greenery Areas (EVP1 and EVP2)}

The design assumptions for green areas included the following: the enlargement of the Parc du Chemin de l'Ile; an increase in the number of trees (about 1000 plants) with the simultaneous protection of open areas, meadows, wastelands, and dry environments; and increasing landscape and species diversity, thus increasing the ecological value. This involved the need to reconstruct the infrastructure, which offered a chance to introduce new plantings along the roads. Two greenery-protected areas have been formed in the area-marked as EVP1 (area 18,162 $\mathrm{m}^{2}$ ) and EVP2 (area 16,269 $\mathrm{m}^{2}$ ). These were included in the local plan (Figure 4). The following provisions entered into force as part of their protection: a ban on cutting trees and disturbing their integral parts, and a prohibition to changing the landscape nature or the plant factor dominance. The removal of a tree is possible only provided that it poses a threat to health, life, or property. This danger must be confirmed by phytosanitary expertise. Additionally, the tree may be removed in the event of remedial measures, e.g., the need to clear the flow of water courses. A consent for tree removal is equivalent to an obligation to compensate for the loss. It was established that the scope of such activities in the EVP area might not exceed 5\% of the total area. The construction of permanent objects cannot exceed the $200 \mathrm{~m}^{2}$ built area. A minimum of $95 \%$ of the protected area must comprise a landscape area, and $80 \%$ is a biologically active zone in the form of open greenery. In the EVP2 area, a height-related limitation for newly erected structures, namely, $5 \mathrm{~m}$, was introduced [62].

In shaping the landscape, it was decided to take systematic actions. They consisted in the reconstruction of the ecological corridor along the Seine and connections related to it. The development method was conducted in line with the neighboring ENS area. Towards the west of the plot, its development has been abandoned. This decision was also prompted by the recognition of the existing flora and fauna. These areas were recognized as part of the internal greenery system and benefited from the connections perpendicular to the Seine. In this way, the Historical Axis of Paris, i.e., public space in the Seine-Arche area, was emphasized, as it constitutes a crystallizing element of the area as well as a natural system element with which green areas of supra-local importance are connected. 
The limitations resulting from natural conditions contributed to the decision to implement compact development forms in the areas facing the Avenue de la Commune de Paris (Figure 8) and in the detention center. The remaining areas, valuable in terms of nature, comprise the landscape (Figure 9).

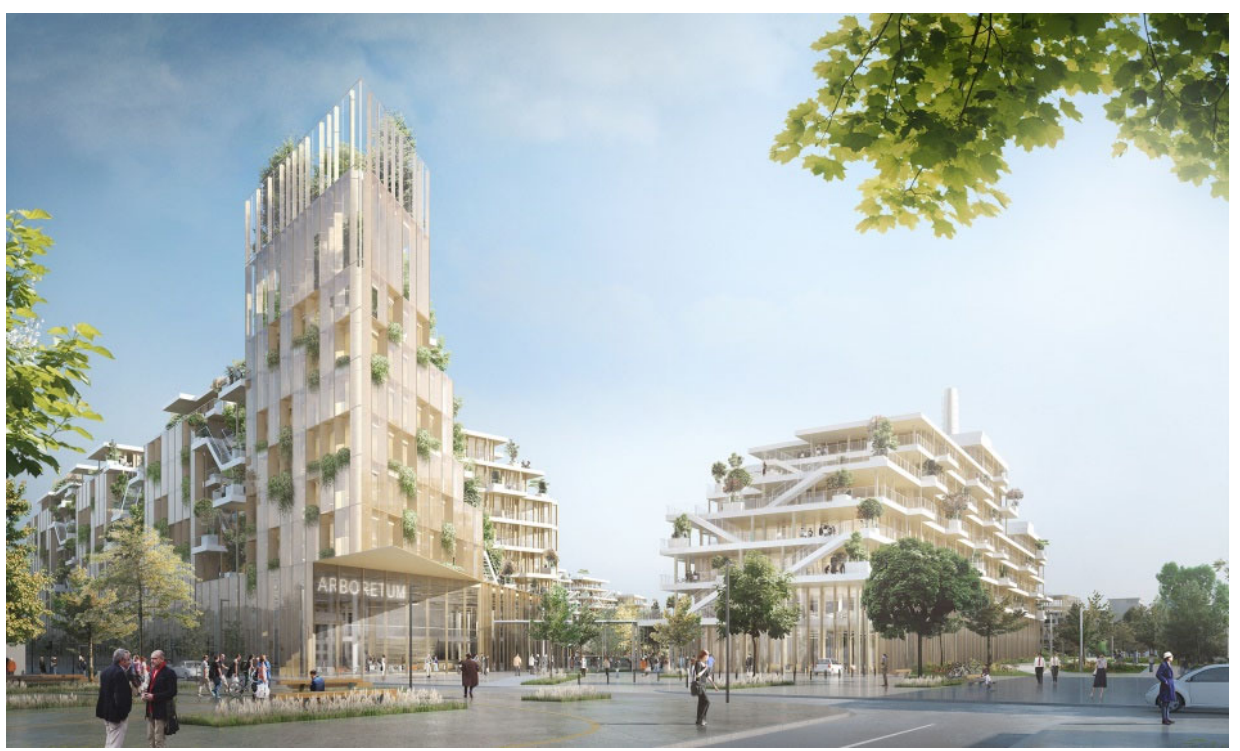

Figure 8. The use of wood as a construction material for buildings as an element of sustainable design (source: Leclercq Associés; Leclercq Associés; Laisné-DREAM, BASE).

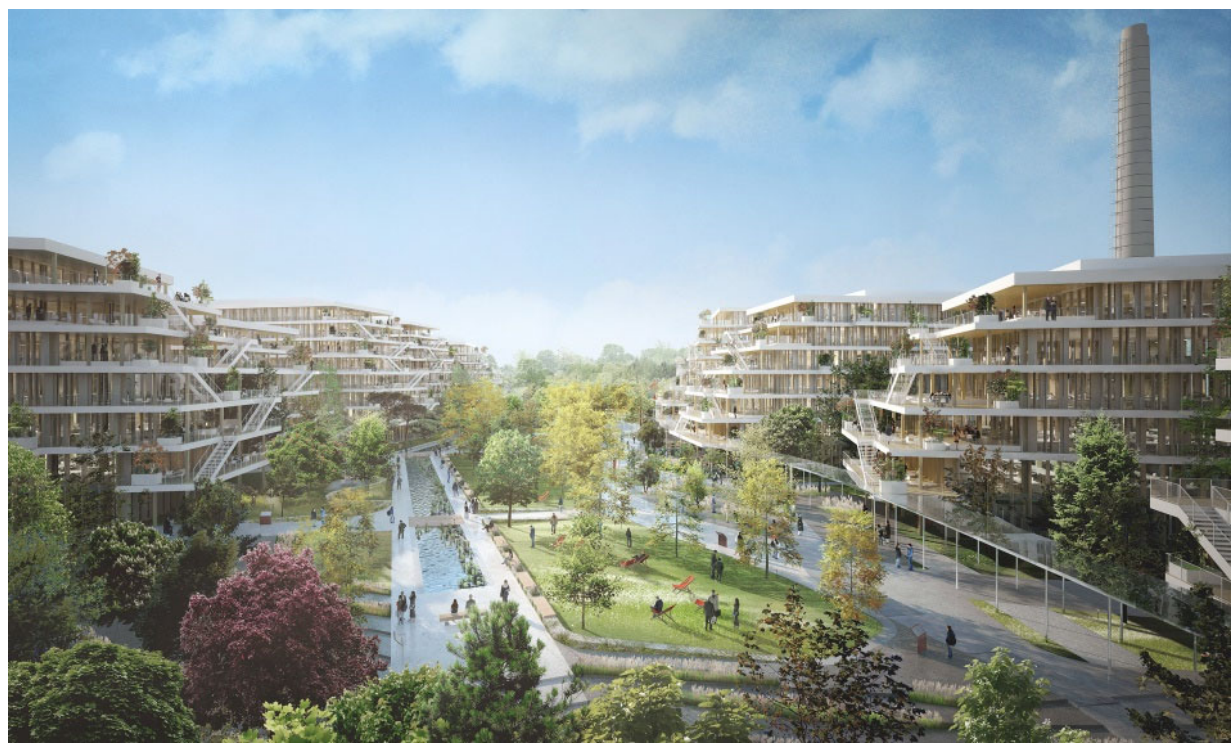

Figure 9. Biophilic way of shaping the form of the complex. (source: Leclercq Associés; Leclercq Associés; Laisné-DREAM, BASE).

\subsubsection{Landscape Solutions in the Project-Composition}

The Parc du Chemin de l'Île (landscape architecture: Mutabilis Landscape Architecture, 2015), with its extension (landscape architecture: BASE Landscape Architecture), acts as a green corridor that connects the public space to the Seine riverbank. The park is of departmental importance. It contains exemplary water circulation solutions and joins other greenery areas. The extension of the Parc du Chemin de l'Île (total area of almost 2 ha) within the former paper mill site forms a green axis towards the Seine.

A new park in the "Arboretum" campsite offers the second greenery area. In its planning phase, the total area amounts to 6 ha. In this park, an innovative approach to 
various types of outdoor practices is implemented (landscape architecture: BASE Landscape Architecture, 2016-17). Landscaping in campus areas exerts a particular impact on the creativity and innovation aspects [100]. In this way, a holistic approach to science is practiced by using the open air as a place for education, thanks to the properties of the green area itself. The open spaces within the campus area also provide opportunities for learning through experience and a sense of belonging to the academic community [101].

The zoning and character of individual places were determined by urban planning indications and the presence of grasslands, as well as by the vicinity of the Parc du Chemin de l'Ile. The open area is divided into two parts, i.e., an open part towards the Seine, and a kind of green ravine between the buildings, the axis of which is provided by a water channel. The area may also serve as a strolling space. The course of the avenues is free, i.e., organic. As part of the green area, small closed enclaves have been designed, which provide a flora and fauna sanctuary.

The traces of the past, such as cranes, rails, tanks, and paving stones, are used in the park's design. The southwestern part is wooded, which refers to the vegetation of the Île Fleurie, an Isle on the Seine.

The diversity in the functional and plant design confirms the assumed biodiversity. Patio gardens, a flowering orchard, grasslands, a green amphitheater, and a vegetable garden were planned. The utility garden crops provide a supply source for a nearby restaurant. The eastern part corresponds more to the meadow landscape. The Arboretum avenue runs through the park and connects all landscape concepts. Places for meetings, cultural events, and outdoor work have been arranged within the parking space. The whole area was arranged in such a way as to ensure natural, visual, and ecological continuity [102].

\subsection{Influence of Social and Economic Conditions (F)}

\subsubsection{Improving Public Health as the Project's Guideline}

The spatial shaping of urban areas significantly affects public health by creating favorable spatial and social conditions, influencing the change of consumption habits, lifestyle, and environmental improvement [36,103,104].

Rich-in-vegetation urban spaces increase exposure to greenery, which positively affects psychophysical health and offers a regenerative environment [105]. This impact may assume a social and individual dimension and may exert a genuine impact on the physical condition (through opportunities for recreation, sport, and a clean and healthy environment) and mental health. The spatial configuration, order, and application of vegetation positively affect the comfortable feeling of the space [106-108].

These aspects are promoted within the framework of health-friendly urbanism (L'urbanisme favorable à la santé-UFS), based on which the Health Impact Assessment (EIS-Evaluation d'impact sur la Santé) was conducted. The assessment was intended to study the impact of the environment and the proposed solutions on the population of the indicated region, with the account to particularly vulnerable groups. The territorial range covered the land quarter of the former paper mill and the detention center, as well as the immediate surroundings. Five main issues related to health and economy were identified, based on which nearly forty recommendations for the project were prepared [109]. The main assumptions and propositions were summarized in APUR report [110]. The Table 3 shows synthesis of all determinants.

According to the above analysis based on public consultations, the focus was on the functional program of the area that is visible. This was mainly due to the need to increase the possibilities for employment for people entering the labor market [108]. Health-promoting factors resulted from the spatial order, the shape of places, and exposure to green areas. These, however, were of less importance, despite their significant impact on health. A review of the source literature on the topic indicates the importance of green areas [111]. The Burton and Grant based on Dahlgren and Whitehead [112] diagram included factors that affect health, depending on the scale of impact, i.e., the personal, local, and general scales [113]. 
Table 3. Thematic scope of the analyses under the Eis procedure for the former Nanterre paper mill area, and proposed solutions. Table by authors.

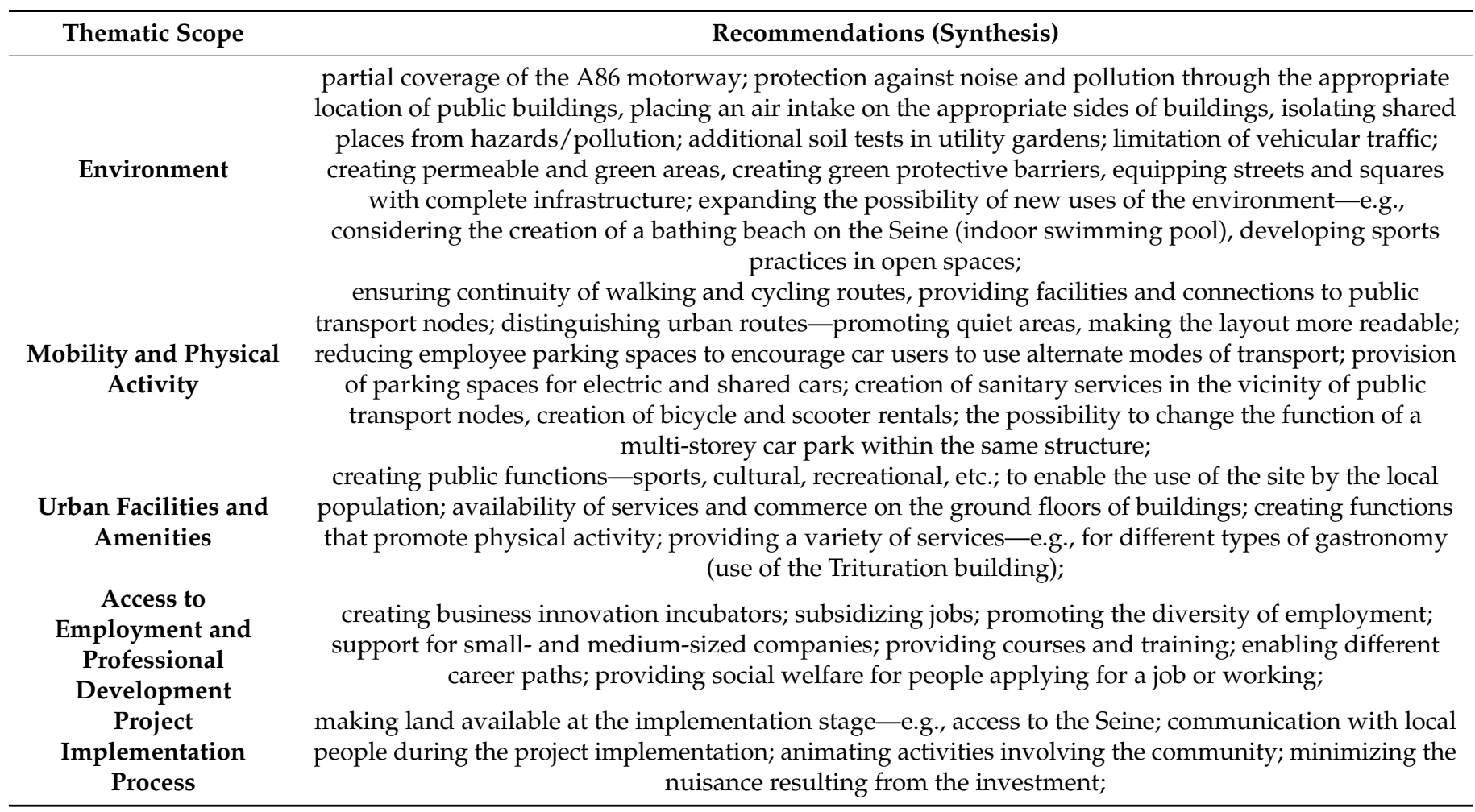

\subsubsection{Area Function, Workplace, Program Variety}

During its operation, the paper mill employed the local population. For economic reasons, it was not possible to maintain the business profile. In 2008-2015, feasibility studies were conducted for various new programs and for the business activity district within the Bords de Seine sector. Ultimately, a mixed program with an indication of strategic functions proved the most optimal. It included innovation developments by expanding the university area, a logistic platform to regulate public transport, and growth possibilities for small- and medium-sized enterprises. The benefits of mixed development include a greater frequency of pedestrian and cycling traffic [114-116] and a more stable employment structure - in line with the principles of a compact city based on smart development [117].

\subsubsection{Communication System}

The contemporary urban development assumes a modification to communication services, mainly to reduce air pollutants and noise emissions. It consists of promoting public transport, cycling, pedestrian communication, electric cars, and possibly car-sharing, all in line with the departmental travel plan (PDUIF) [118].

The existing communication system strongly impacted the functional and spatial system by cutting off the area from the city with communication arteries. Urban-planning activities led to the integration of this area.

The communication development strategy in the former paper mill area implements the idea of creating an appropriate urban tissue density that is friendly to pedestrians and cyclists, and connecting it to the Transit-Oriented Development (TOD) traffic [119]. It is estimated that this approach may reduce $30 \%$ of greenhouse gas emissions, compared to conventional traffic [120].

One solution within this system comprises optimizing the freight-delivery system by planning an intermodal logistics platform to serve the Nanterre and La Défence area using river transport. The facility is functionally related to the Seine, while the individual zones of the platform are adapted to the unloading, storing, and receiving of transport 
functions. By locating the object in a given place, the properties of the urban tissue with the appropriate development intensity are applied.

The public transport node (Nanterre-Universite railway station) is $700 \mathrm{~m}$ from the former paper mill site. The station constitutes a junction of the SNCF L and RER-A lines and is connected by the Rue Anatole France route, which leads to the investment area. A new element in the form of the designed T1 tram line is introduced to connect Nanterre and the neighboring community of Rueil.

Following the current plan of walking trails (Plan départemental des itinéraires de promenade et de randonnée-PDIPR) [121], two routes have been mapped in the area of the former paper mill (on the shore and towards the island on the Seine), with the indication that the routes should be greenery-covered and landscape-related.

The spatial effects of changing the communication strategy resulted in a visual minimization of the road infrastructure and its environmental impact. In functional terms, the area was provided with better communication of sites located along the Seine riverside.

\subsubsection{Social Importance of Public Space}

Due to the social impact, three significant places located on the former paper mill site can be distinguished. These include the extension of the Parc du Chemin de l'Ile, the internal green area of the campus, and the Avenue de la Commune de Paris street with active commercial frontages. A mosque was also built in this street, as well as an entrance area to the campus.

The campus area has been planned as space available to people from the outside, as it offers sports and catering services, as well as the possibility of organizing outdoor events.

\subsection{Actions against Anthropopressure and Factors That Degrade the Urban Environment (G)}

The condition of the environment affects both the health of city dwellers and the social conditions. Currently, it is recognized that bad environmental conditions (poor air cleanliness, high noise levels, poor soil quality, nuisance, etc.) may lead to certain social exclusion and cause social segregation by inequalities in living conditions. Dempsey et al. develop this problem in research on the "sustainable social development of cities" [122,123].

Under European and French law, the former paper mill development project was required to be preceded by an environmental assessment and an environmental impact assessment. In the Regional Health and Environment Plan for Ile-de-France in force at the investment time (Plan Régional Santé Environnement-PRSE 2), the goal was established to reduce environmental inequalities [124]. As part of the report prepared for the 2016 plan, areas with a high environmental burden were selected-the so-called environmental black spots (PNE-Points Noirs Environnementaux). The area of the former paper mill was classified as such an area. In the qualification of PNE points, five indicators were used as the criterion for which the limits of exceedances were defined. These included: air pollution, noise, soil condition, water pollution, and industrial contamination. On the premises of the former paper mill, the first three indicators proved the most important. The following preventive measures were specified: the proper orientation of buildings, the use of noise barriers, greenery designs, the proper location for public spaces, the proper orientation of the building's air intake, and the removal of pollutants.

\subsubsection{Air Quality}

Air quality testing within the former paper mill area revealed the presence of the following pollutants: $\mathrm{NO}_{2}, \mathrm{PM} 2.5, \mathrm{PM} 10$, benzene, and ozone [110]. According to local measurements, the negative impact of nitrogen dioxide emitted by car traffic on motorways ranged as far as $200 \mathrm{~m}$ from the emission source. Measurements of air pollution within the former paper mill area indicated the highest permissible value exceedances in the vicinity of the A14/ A86 motorway junction, i.e., in the southern and western zones. The average for $\mathrm{NO}_{2}$ equaled $62.03 \mu \mathrm{g} / \mathrm{m}^{3}$ (with the standard of the quality target at $40.00 \mu \mathrm{g} / \mathrm{m}^{3}$ ), for 
benzene- $-1.3 \mu \mathrm{g} / \mathrm{m}^{3}$ (at the edge of the norm). In other local background locations, these values reached 44,65 , and $1.1 \mu \mathrm{g} / \mathrm{m}^{3}$ [110].

The adverse health effects of PM 2.5 air pollution are well established. Research on the French population has shown that these pollutants cause about 48,000 deaths annually, contributing to $9 \%$ of all cases. Moreover, they reduce the average life expectancy by two years (for every thirty years lived) $[125,126]$.

The identification of air quality hazards at an early investment stage made it possible to counteract the effects. This can be achieved by the proper location of buildings, the use of buffer zones to separate pollutant emission sources, the proper orientation of the air intake, changing the transportation system to lower emission ones, and, above all, introducing compact greenery areas. Such activities were undertaken within the framework of the ZAC des Papeteries. The recommendation to counteract pollution effects concerned the application of such security measures while shaping the architecture and technical devices that would protect people inside buildings [110]. The reconstruction of the A14/A86 junction was of great importance, as it deemed the removal of the buildings away from the motorway line necessary.

\subsubsection{Noise}

Noise poses an equally important threat to the development of a sustainable environment and health. Mental stress usually occurs at noise-related discomfort at the level between 60 and $65 \mathrm{~dB}(\mathrm{~A})$. This is a personal perception, depending on individual bioavailability. However, as has been scientifically proven, the effect of night noise on the body's response and health is already detrimental at the level of 30-40dB (A) [127]. Such environmental properties do not correspond to the conditions required from a university campus area, i.e., the proposed dominant function in the former paper mill.

The following noise sources have been identified within the site: the A14 and A86 motorways, the RER A and TER L railway lines, and planes taking off and landing at Roissy Charles de Gaulle airport. The width of the most burdensome impact zone from the A86 motorway was determined at $300 \mathrm{~m}$. The background noise level was estimated at 65-70 dB (A), and as much as 70-75 dB along communication routes (A). In terms of noise, the area was classified as a moderate arduousness zone due to the terrain differences that cause a dampening of the noise [110].

The fact that the A14 and A86 motorways junction was located at a depression transformed the Avenue de la Commune de Paris into an urban boulevard. The new campus and the Nanterre Universite railway station were safely connected by extending Rue Anatole France. Limiting the noise in critical places (e.g., at the point of crossing an arterial road) is essential for pedestrian and cyclist safety. Scientific research in the field of an acoustic environment shows that noise may affect the deterioration of spatial orientation and thus affect the auditory and visual modality [128].

This factor is of great importance in ensuring locomotion safety in the city. At the design stage, solutions for a safe, collision-free crossing on the extension of Rue Anatole France were proposed.

In addition, strategies for limiting noise effects were applied. These solutions are universal and include the following: limiting noise sources themselves, using appropriate distances for residing places, recreation, sports, using acoustic barriers (e.g., screens, dense greenery), introducing appropriate security measures in the building, etc. [129].

\subsubsection{Industrial Contamination}

Environmental problems, whose sources were located within the investment boundaries, were distinguished and compiled according to different types and levels of pollution. The areas most challenged by the adverse effects were indicated. Preparing the area for safe use and planning decontamination works was crucial. Industrial contamination, mainly soil contamination related to the operation of the paper mills, was demonstrated in two studies: BASOL [130] and BASIAS [131]. Environmental studies were conducted in various 
periods: from 2010-2012, after the cessation of production, in 2014, and later, to establish the $\mathrm{ZAC}$ zone.

The activities to cease the functioning of the paper mill involved the following steps: removing the radiation source in the machinery building; the disassembly of industrial installations, including oil and grease storage and storage tanks, the decommissioning of a transformer which contained polychlorinated biphenyls; the removal of biological sludge from the water treatment plant on the premises of the plant (decommissioned in 2010). Boreholes in the vicinity of industrial installations have proved the presence of the following substances: PAHs - polycyclic aromatic hydrocarbons, PCBs—-polychlorinated biphenyls, and polychlorinated terphenyls (PCTs), and chlorinated tricholethylenes solvents [130].

Additionally, based on the BASIAS study, a storage area for bituminous materials used for road works has been identified (IDF9207091) in addition to the paper mill area (IDF 9200496) [131].

Decontamination works conducted in 2014 enabled the adaptation of the site to the proposed service functions and the needs of small- and medium-sized enterprises. It was assessed that the works were compliant with the 2013 environmental decision, based on which the operator of the site was required to conduct repair works [71].

After the decontamination works, the partial risk analysis of 2015 showed that the area posed no threat for establishing service, production, or housing functions, should they be necessary for proper land use [130].

On the site of the former asphalt plant, in operation in 2017 during the A14 motorway (1966) road construction, thirty-one boreholes were drilled to a depth of $6 \mathrm{~m}$. These studies showed contamination in the form of backfill with heavy metals, THCs-total hydrocarbons, PAHs - polycyclic aromatic hydrocarbons, and PCBs-polychlorinated biphenyls. Part of the backfill was designated for hazardous material storage in waste plants [71,131].

Taking the fieldwork into account, including the slopes and excavations to be shaped for two underground levels, the need to export over $16,000 \mathrm{~m}^{3}$ of soil was estimated [71].

In conclusion, decontamination work was performed with regard to contaminants. The above-mentioned activities towards removing harmful pollutants and contamination did not constitute a determinant for limiting the urban or architectural form design.

Decontamination works, however, had an impact on the progress of preparatory work and on-field works, by which the topography was shaped.

\subsubsection{Construction Waste Management}

Following the construction waste management obligation, the investor was required to take measures in this regard. The following activities are commonly recommended: the reuse of construction waste (if possible), recycling, composting, and use for energy production [132]. Regional regulations govern waste management in the Ile-de-France area. For industrial plants, these are separate regulations [133]. Wastes are classified depending on their environmental impact. It is estimated that construction waste accounts for over $50 \%$ of all waste [81].

The construction waste management plan (Plan régional de prévention et de gestion des déchets de chantiers-PREDEC) assumes the following objectives: waste inventorying, determining storage possibilities, processing, storing, and defining recovery targets and reducing storage, determining the possibility of using recycled materials, and preparing environmental assessment [134].

The 2017 inventory enabled the grouping of the waste and estimating its quantity as follows: ordinary waste -309 tons, concrete $-116,000$ tons, rubble $-22,000$ tons, scrap1371 tons [135]. Asbestos-containing materials were identified as floorboards, cement-glass boards (roofing), sealants, adhesives, paint, and thermal insulation [136]. Storage on special, separated pallets for asbestos-based materials was prepared, together with a disposal plan.

The following architectural heritage elements of decorative significance were intended for reuse: brick walls $\left(230 \mathrm{~m}^{3}\right)$, ceramic and cobblestone floors $\left(200 \mathrm{~m}^{2}\right)$, and metal rails. These applications influenced the architecture of the area. The reuse of concrete is intended 
for the main foundation in the logistic platform roads (approx. $45,000 \mathrm{~m}^{3}$ ) and as aggregate in concrete once the physical and chemical properties are defined. The total amount of reuse of these materials is estimated at 50 tons [71].

These activities mitigate the demand for waste-disposal trucks.

Actions to counteract environmental threats mainly consisted of eliminating the sources of these emissions and shaping a user-safe environment.

\section{Results}

Table 4, below, presents a comparison of factors determined into groups of the problem issues (A-G), with groups of design solutions depending on their impact scale: I-city scale; II-the scale of the ZAC zone; III-architecture, landscape architects and green infrastructure, while group IV comprises the transformation process itself. The consideration of process is legitimate because it influenced the choice of a design approach. This is not a commonly considered aspect in the analysis of the state of the research conducted. Such action is aimed at assessing the impact of the above-mentioned analyzed determinants on individual project areas.

Table 4. The impact of various aspects of the existing state on design solutions in the scale of a city, area, designed facilities and the implementation process. Study by the authors, 2021.

\begin{tabular}{|c|c|c|c|c|c|c|c|c|c|c|c|c|c|c|c|c|c|c|c|c|c|c|c|}
\hline & \multirow{4}{*}{\multicolumn{2}{|c|}{ Existing State }} & \multicolumn{21}{|c|}{ Assessment of the Impact on Design Solutions } \\
\hline & & & \multicolumn{5}{|c|}{$\begin{array}{l}\text { I-Urban } \\
\text { Solutions-Relations with } \\
\text { the City }\end{array}$} & \multicolumn{7}{|c|}{$\begin{array}{l}\text { II-Urban and Architectural } \\
\text { Solutions—the Scale of the ZAC des } \\
\text { Papèteries de la Seine }\end{array}$} & \multicolumn{5}{|c|}{$\begin{array}{l}\text { III-Architecture and } \\
\text { Landscape } \\
\text { Architecture, Green } \\
\text { Infrastructure }\end{array}$} & \multicolumn{4}{|c|}{$\begin{array}{l}\text { IV- } \\
\text { Implementation } \\
\text { Process }\end{array}$} \\
\hline & & & Ia & Ib & Ic & Id & Ie & IIa & $\mathrm{IIb}$ & IIc & IId & IIe & IIf & IIg & IIIa & IIIb & IIIc & IIId & IVd & IVa & $\mathrm{IVb}$ & b IVc & IVd \\
\hline & & & 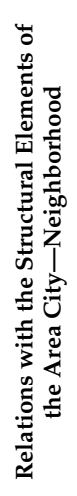 & 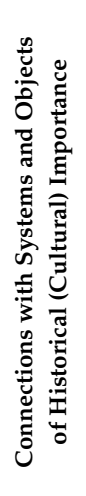 & 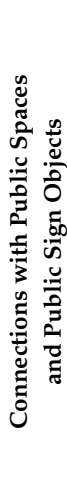 & 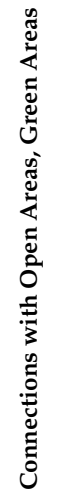 & 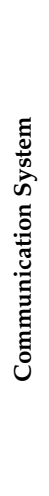 & 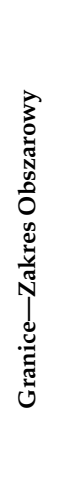 & 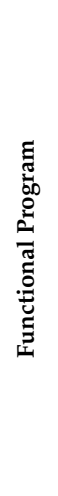 & 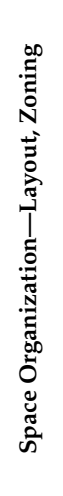 & 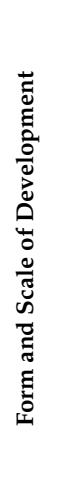 & 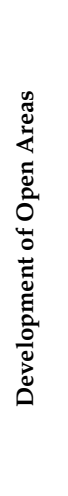 & 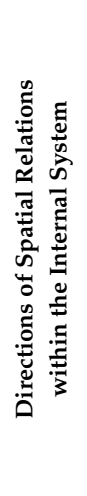 & 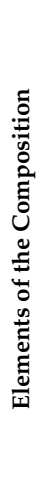 & 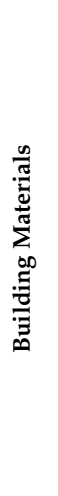 & 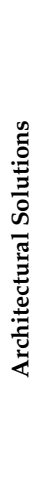 & 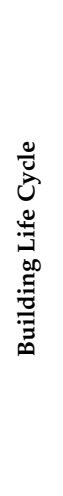 & 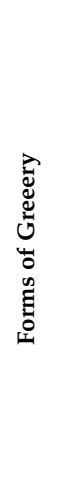 & 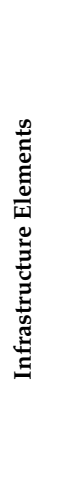 & 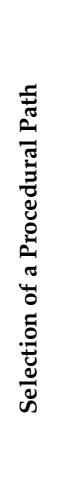 & 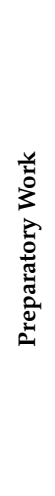 & 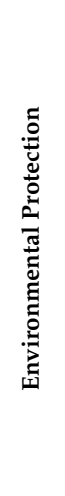 & 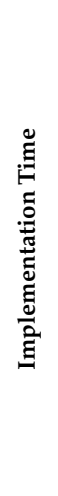 \\
\hline \multirow{3}{*}{ 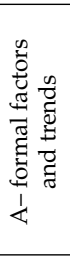 } & & $\begin{array}{l}\text { land parcelling } \\
\text { and ownership }\end{array}$ & & & & & & +++ & ++ & ++ & ++ & & & & & & & & & +++ & & & \\
\hline & A2 & $\begin{array}{c}\text { regional and } \\
\text { local } \\
\text { development } \\
\text { plans, legislation }\end{array}$ & +++ & +++ & +++ & +++ & ++ & +++ & +++ & & +++ & & ++ & + & & ++ & & & & +++ & & & \\
\hline & & $\begin{array}{l}\text { ideological } \\
\text { concepts, trends, } \\
\text { etc. }\end{array}$ & ++ & + & + & ++ & ++ & & ++ & ++ & ++ & +++ & ++ & + & ++ & ++ & ++ & ++ & ++ & +++ & ++ & ++ & ++ \\
\hline \multirow{3}{*}{ 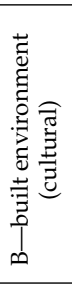 } & B1 & $\begin{array}{l}\text { structure of the } \\
\text { city-layout, } \\
\text { tissue }\end{array}$ & +++ & + & ++ & ++ & ++ & & ++ & +++ & & & ++ & & & & & & & & & & \\
\hline & B2 & $\begin{array}{l}\text { the form and } \\
\text { layout of the } \\
\text { development of } \\
\text { the area }\end{array}$ & & & & & & + & & & & & & + & & & & & & & & & \\
\hline & B3 & $\begin{array}{c}\text { visual } \\
\text { environment- } \\
\text { aesthetics }\end{array}$ & ++ & & ++ & ++ & & & & & ++ & & & & & ++ & & ++ & & & & & \\
\hline \multirow{4}{*}{ 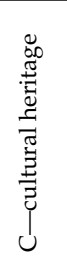 } & $\mathrm{C} 1$ & archeology & & & & & & & & & & & & & & & & & & & + & & \\
\hline & $\mathrm{C} 2$ & $\begin{array}{l}\text { historical } \\
\text { heritage }\end{array}$ & + & + & & & & & & & & & & & & & & & & & & & \\
\hline & C3 & $\begin{array}{l}\text { elements of } \\
\text { industrial } \\
\text { heritage: layout } \\
\text { and facilities }\end{array}$ & & & & & & + & + & & & & & ++ & + & ++ & & & & ++ & ++ & & \\
\hline & $\mathrm{C} 4$ & $\begin{array}{c}\text { intangible } \\
\text { heritage items }\end{array}$ & & & & & & & & + & & & & & & & & & & & & & \\
\hline
\end{tabular}


Table 4. Cont.

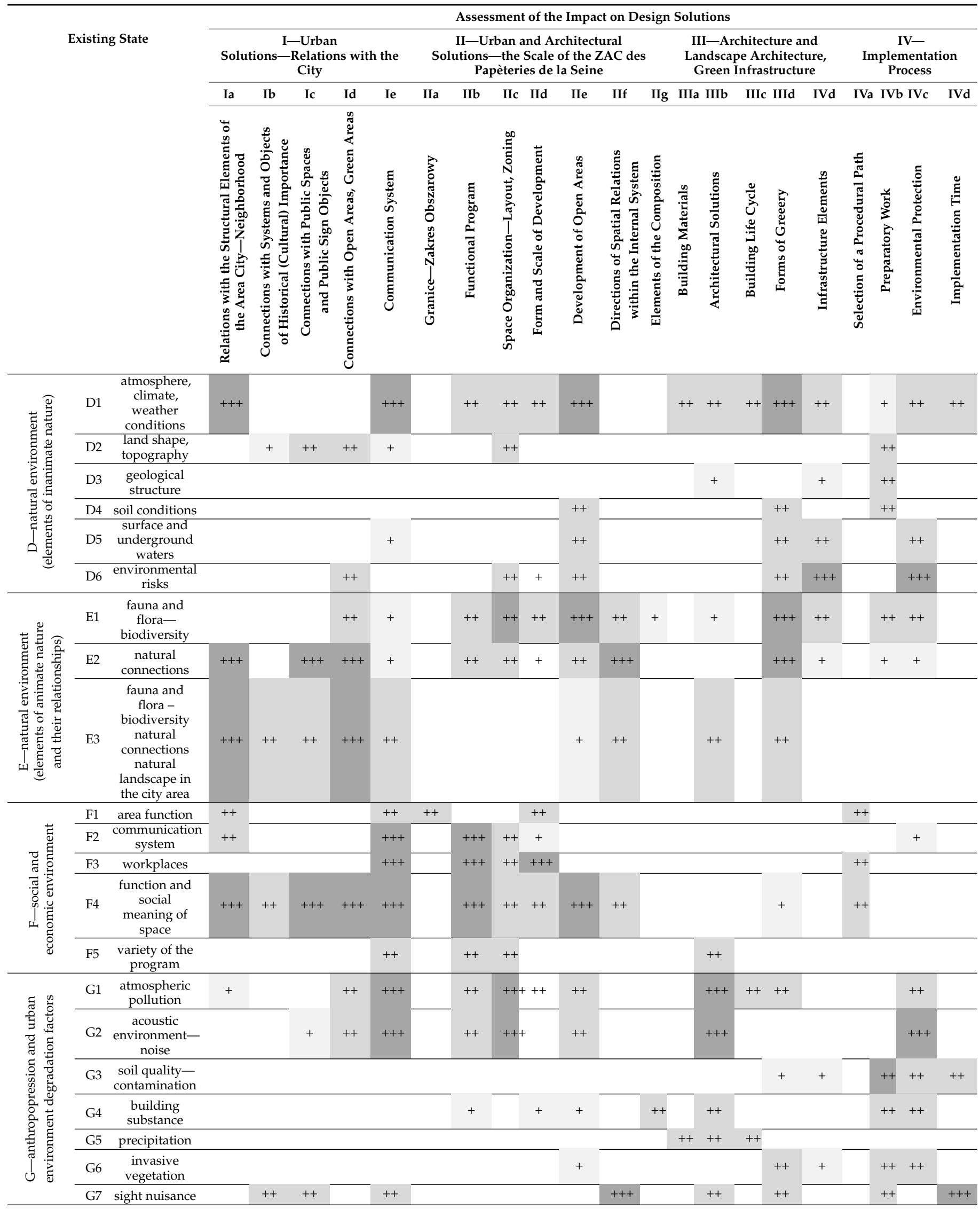

The designation: +++-significant impact, ++- medium impact, + -minor or general impact. 
Groups of problem issues related to the existing state, i.e., D and E, comprise groups of factors related to the natural environment (abiotic and biotic). They constitute important design conditions both on the city and area scale. In this group, the biosphere components that influenced design decisions emerged as worth protecting. Group G comprises risk factors resulting from anthropopressure, for which the following actions are recommended: elimination, reduction, combating, or securing. All three groups (D, E, and G) consist of environmental condition elements. The remaining groups $(\mathrm{A}, \mathrm{B}, \mathrm{C}$, and $\mathrm{F})$ create conditions related to the spatial, economic, and social order. They refer to environmental issues indirectly.

The presented assessment is organized in the form of a three-level scale. It discusses the level of influence exerted by given factors on design solutions. These can be defined as follows: significant impact $(+++)$, medium impact $(++)$, minor or general impact $(+)$. In terms of quantity and importance, environmental factors account for approximately $50 \%$ of all determinants.

Based on the analysis as a whole, it can be concluded that the following factors played a significant role:

- change within the communication system, forced by environmental factors;

- creating landscape connections (also: ecological and visual)-opening to the Seine valley, connecting with other elements of the city's natural system-e.g., Parc du Chemin de l'Ile;

- the protection of grasslands, introducing elements of surface water and wetlands into the landscape - the protection of biodiversity; creating refuges for flora and fauna;

- the use of the landscape nature of the campus for the development of educational and social practices outdoors;

- the use of wood in the construction of academic facilities;

- the use of surface water and greenery to create a microclimate of the place-leveling the effects of urban heat islands;

- the minimization of sealed and built-up areas for the drainage of rainwater within the plot;

- $\quad$ creating a buffer zone with greenery facing the railway;

- $\quad$ shaping the topography with the use of earth masses from a given area.

Significant differences in shaping the form can be noticed when comparing the preliminary design before 2017 to the current one (after extensive environmental analyses). The greenery interior of the complex was extended towards the Seine and a water canal was introduced, along with a wetland. Initially, it was assumed that the greenery areas in the western part would be built-up. The greenery area near the railway has been widened as a buffer zone to suppress noise. The road connection towards the Seine has been transformed into a park (Figure 10).

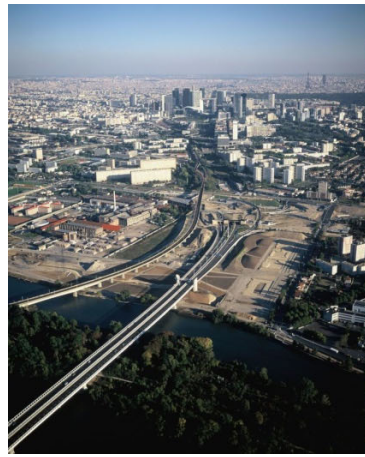

(a)

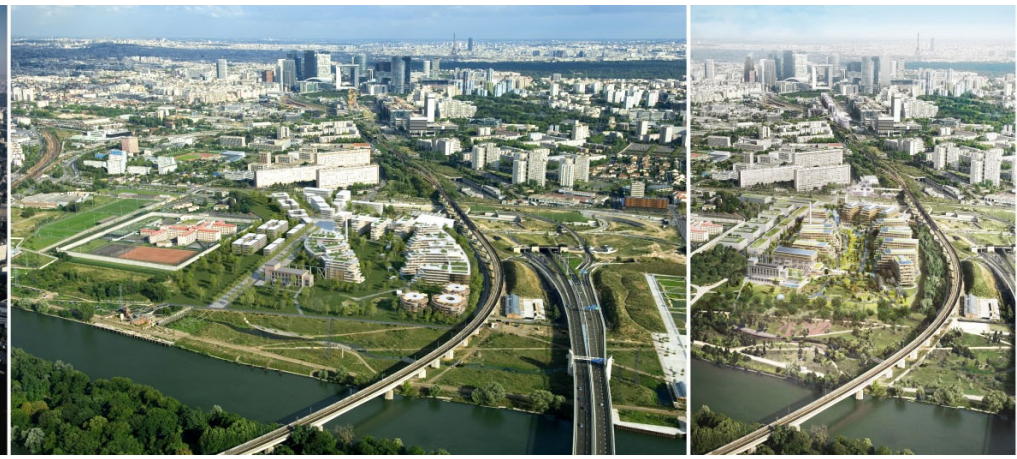

(b) (c)

Figure 10. Comparison of the three management options: baseline (a), preliminary project before 2017 (b), target project-2021 (c). The photographs show the landscape-the connection with the Seine valley and the scenic connection with the Historical Axis of Paris (La Defense in the background). (source: Leclercq Associés.). 
Based on the results in Table 4, the relationships between the groups were established.

All impact levels were influenced by: A2, regional and local plans and legislation; A3, ideological concepts, trends, etc.; D1, atmosphere, climate, weather conditions; E1, fauna and flora-biodiversity; E2, natural connections.

The issues contained in the following groups had a significant impact on the city and area scale: A-formal factors; E-the natural environment; F-social and economic environment; and G-concerning anthroporesia and factors degrading the urban environment. Protection against air pollution and noise was vital (G1 and G2). A close relationship with campus landscape-shaping can be observed in the D and E groups of factors. Group $\mathrm{G}$ was essential in planning the investment process.

For technical reasons, only two buildings could eventually be adapted to new purposes despite the assumptions that the industrial heritage should be included in the architectural complex. The chimney, a characteristic element of the campus composition (intended as a dominant feature), was demolished during the construction phase due to its poor technical condition. To sum up, regardless of the potential of the historical factor, it has not become a guideline for new transformations.

The obtained spatial form assumes the biodegradable architecture dimension. However, rather than resulting from the adopted aesthetic criteria, the form responds to environmental guidelines and problems. In Table 5, using the criteria of biophilic architecture according to Browning [42], solutions and spatial features which determine the biophilicity in the former paper mill design were selected.

Table 5. Assessment of the biophilic character of the development of the ZAC des Papèteries de la Seine area.

\section{Elements/Criteria of Biophilic Design [42]}

visual connections with nature

non-visual connections with nature

non-rhythmic sensory stimuli

variability of temperature and airflow

the presence of water

the presence of water

connection with natural systems

biomorphic forms \& patterns

material relationship with nature complexity and order

view

shelter

mystery/mysteriousness

risk/hazard elements
Application in the Design of the ZAC des Papèteries de la Seine Area or the Natural Conditions of the Site

ecological and scenic connection with the Seine valley and with the Parc du Chemin de l'Ile; elements of green infrastructure included in the architecture of facilities;

the industrial area was devoid of natural elements but benefited from local conditions (e.g., river transport was used); variability, seasonality typical of open areas with greenery-the influence of natural light, birds singing, etc.;

above the ground surface, open areas susceptible to weather variability were designed;

the water layout in the former paper mill—referring to the Seine and the layout of the nearby park-serves as a habitat for avifauna and supports drainage and purification of rainwater;

trees and other greenery diffuse natural light; connection with the ecosystem of regional importance-the Seine valley and Parc du Chemin de l'Ile;

layout partially open-adjusted to the landscape interior, greenery elements within the building (facade-pots on terraces, roofs); wood as the primary construction material;

the form of the building uses a modular element-softly shaped; green areas play the role of open areas; they are surrounded by buildings-a layout of mutual viewing;

in the grasslands, there are quiet enclaves inaccessible to users-serving as fauna habitats; shaping places for users also involves small and large interiors;

open areas include enclaves-small landscape interiors, landscape screens, multi-planed layout; the risk related to weather variability in open areas. 
The results presented above support the thesis that an emphasis on environmental issues results in the emergence of biophilic forms. One piece of evidence is that previous feasibility studies have produced a very different spatial effect.

In this case, many solutions have a universal dimension, which can be applied to other sites:

- $\quad$ making the natural system more readable in urban structure;

- $\quad$ highlighting the landscape values of a river valley;

- $\quad$ seeking landscape continuity;

- $\quad$ the protection of flora and fauna habitats (possible compensation of development elsewhere in the plot);

- $\quad$ the creation of wetland habitats;

- $\quad$ the use of water to create microclimate of the site;

- $\quad$ a high degree of greening (use of various forms of greenery, green infrastructure);

- the creation of enclaves excluded from active use;

- $\quad$ shaping the topography with the use of earth masses from the site;

- $\quad$ the use of natural materials as building material-e.g., wood;

- $\quad$ the creation of soft forms, referring to natural forms.

The example of the former paper mill confirms that the change in the design process with an emphasis on environmental issues influences the result-the idea of new developments. The key aspects for the architectural form of the complex turned out to be the protection of local resources, the highlighting of ecological connections, and the protection against harmful effects mainly from communication. From the environmental point of view, they are essential. Referring to Tabb's division, these are place-based factors [45]. The use of forms imitating nature or related to nature - the use of vegetation in the facades and the use of wood material for the construction of the building-was also important. This aspect has a visual value. These elements were based on patterns of nature and characteristics of nature [45]. Combining these two groups is a free form that is reminiscent of a canyon or river valley and, therefore, has a reference to nature. Another of the patterns captured by Tabb, the way resulting from forms, was not created separately but was the result of the combination of two others (Figure 11).

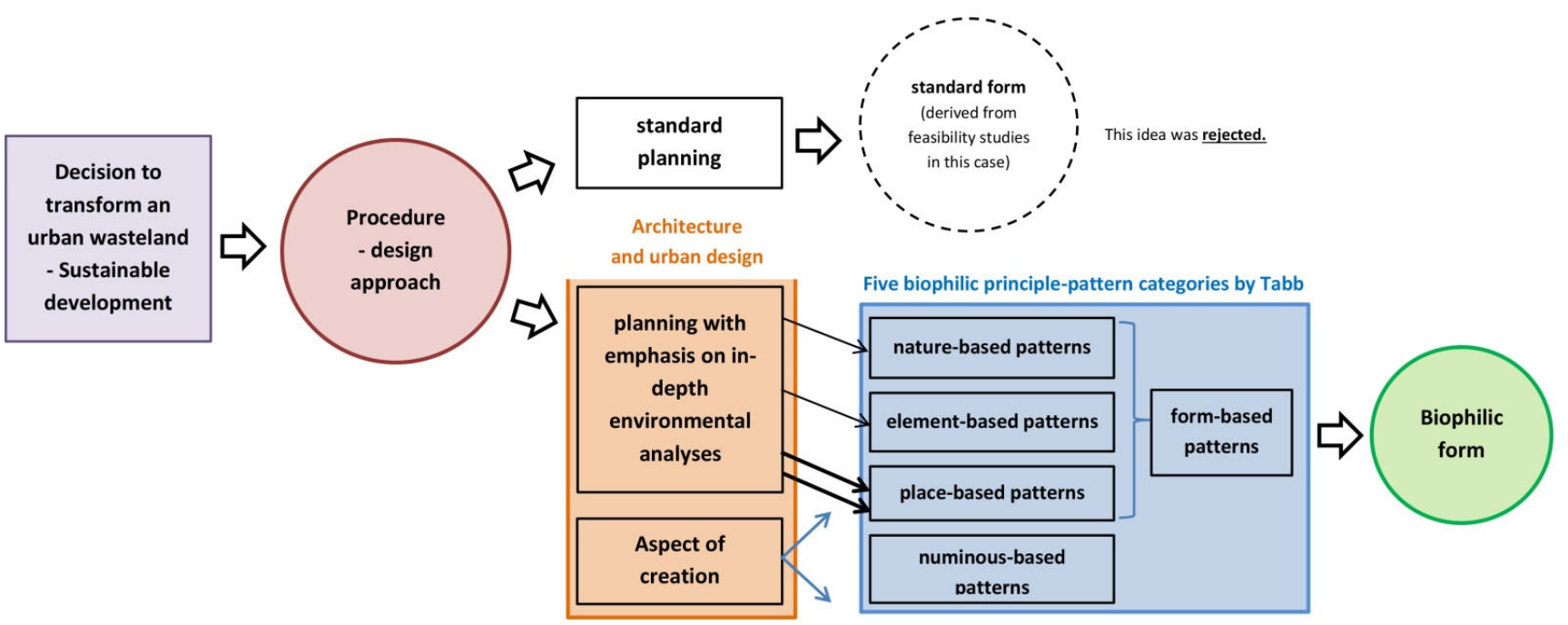

Figure 11. Model for a process of biophilic form creation.

As in the case of Kellert and Willson, a division into organic aspects (inspired by nature) and those resulting from the place is visible [41].

Although Andreucci et al. divide biophilic forms into three scales, they do not take the process into account. They note, however, that in multi-criteria and interdisciplinary projects, the coordination aspect is essential [46]. This can be provided by a formal approach 
that takes into account the planning procedures, or by a very highly professional project team. However, in the latter case, this is not guaranteed.

The most common biophilic elements are all elements that exploit the aspects of vegetation, spatial order, and connectivity with other elements of nature.

\section{Discussion}

Global environmental requirements and local conditions impact urban and architectural forms that assumes a biophilic dimension. Initially, knowledge of cities and ecology stood in opposition to each other. Currently, the coexistence of these two development areas is required. In the revitalization or transformation of urban areas, biophilic architecture is vital with regard to participation and social outlook. It strengthens the relationship between humans and nature [28].

In the course of works on urban concepts, various arguments clashed in the social discourse. Historians and history lovers from the local association raised issues of placeidentity preservation: "Elected officials, project managers, users and citizens-they all want to build the city of tomorrow, a sustainable city, but shouldn't we stop destroying the surviving city?" (Translation by the author) [137]. According to the approach presented by Cappai et al. [138], social consent, identity-seeking, and consultation with various stakeholders are crucial for transforming former industrial sites but are often overlooked. In the case of the area in question, the consultations mainly focused on the availability of new jobs. Environmental proposals emerge from expert studies and regulations. The aspect of the total management makeover takes no account of the social relations of a person with the place, which can be defined as an attachment, habit, familiarization, etc. [139].

In order to effectively (economically and sustainably) reintegrate the areas into the local and regional system, namely, to define priority objectives, user assessments should be conducted at an early planning stage in the revitalization process [140].

Another approach to comparing the design conditions is to use groups of social and economic factors and to use the values of indicators [138,141,142].

This approach can serve as an extension to the method. The above study covers such issues, with the possibility of a framework assessment thereof, e.g., in terms of connections that impact the shaping of the form.

Abdelaal presents biophilia as a philosophical approach that strongly influences the improvement of physical, social, intellectual, and psychological well-being [51]. According to Jones, the concept of a "biophilic university" provides an element of narrative and heuristics [143].

In the research presented in the above article, biophilia results from pro-environmental activities and is perceived in terms of spatiality and design. In most studies, biophilia is associated with sustainability. It is seen in campus solutions, which can provide predictive practices for cities in implementing biophilic design values and patterns.

The biophilic approach more often constitutes a sustainable development tool than emerges due to environmental factors. In the research by Revell and Anda, biophilia is given an aesthetic dimension that translates into regenerative landscapes, shaping ecological responsibility, ecological management and intellectual benefit [144].

Case studies conducted by other researchers on the aspect of biophilicity lead to different conclusions.

Brokking et al. conclude that nature-based solutions (NBS) are an important aspect of spatial planning, but the examples given do not indicate that the layout of new development adapts to environmental conditions. Rather the land use itself contains biophilic solutions. Three examples from Stockholm, Fyrklövern, Täby Park, and the Stockholm Royal Seaport, generally present traditional quarter development-typical of Swedish urban planning [145]. In the paper mill case, the form and layout of the buildings have resulted from the environmental conditions.

This aspect of the distinction between the biophilicity of the site and the development is highlighted in the work of Panlasigui et al. [146]. This raises the question of whether 
site-planning should not be holistic and also take into account the spatial aspect of the facilities. From the point of view of human perception, this is of importance. Man's stay in the natural environment changes his attitude towards nature [28,147].

Blau et al. distinguished between regenerative and conventional designs as two methods with different foundations [148]. Regenerative design, according to the researchers, goes beyond sustainable design because it adopts a holistic and not a reductionist attitude. According to this definition, the new development of the paper mill is such a regenerative environment. The cited area from Portugal in the city of Albufeira takes a biophilic form. The quarters adapt to the place in three dimensions: atmosphere, function, and space [148].

Birmingham, which belongs to the network of biophilic cities [149], introduces systemic solutions into urban plans [150]. However, it is difficult to assess the form of the city as a whole, as it is a multi-year process and is currently at an early stage. However, it would be interesting to examine some smaller areas in Birmingham, concerning these provisions.

\section{Conclusions}

A framework comparison of environmental conditions and their reference to solutions on the city, facility, and detail scale may serve as a model example for this type of urban revitalization/transformation or assessments thereof. Based on further work, the model can be developed and transformed. A study for any transformed urban unit (with division into land use and the scope of the analyzed issues) can be used for such goals as the transformation assessment-e.g., in terms of access and benefits from the introduced ecosystem services, or pro-health aspects of the urban environment.

Rather than being only an aesthetic practice or architectural creation, the trend towards using biophilic forms stems from the interaction between environmental conditions and the proposed new site development.

The analysis of the case study-based research has led to the following statements:

- $\quad$ Nature-based solutions (NBS) do not always lead to biophilic forms. This depends on the accumulation of biophilicity criteria. The multifaceted nature of environmental conditions is the source of the emergence of a biophilic form in the form of layout and built form;

- Systemic planning solutions strongly support the development of biophilicity, and do not determine the form of areas completely but may have a dimension at the scale of the entire city (e.g., by strengthening ecosystem connections or a greater share of greenery in the development of individual areas). The choice of a formal approach with an in-depth environmental analysis is a key aspect that provides the opportunity and suggestion to implement this type of project;

- Usually, the identification of biophilicity is made based on criteria: Beatley, Kellert, Browning, etc. Spatial, perceptual aspects resulting from the research experience of environmental psychology can be added to these indications;

- The formal process has an impact on the design approach.

The emphasis on environmental issues in these types of projects (important now and in the future) is very strong. It displaces the approach focused on the past, historical identity of the place.

A holistic approach to the problem of urban transformation focused on environmental aspects results in the emergence of biophilic forms as a need for the environment and a new aesthetic dimension in architecture and urban planning.

While analyzing the conditions and the solutions proposed for the new layout, i.e., mainly consisting of the University of Nanterre office campus (Campus Seine-Arboretum), it can be argued that the environment has determined the development form. This is visible both in relation to the functions offered by individual zones and the space that combines elements of culture and nature in a sustainable manner.

The result of the study showed that the process of choosing a design path and carrying out thorough environmental studies is very important. It affects the elements at three scales: the urban unit city, the site, and, additionally, in terms of process. In addition 
to the environmental sustainability benefits gained, this approach is an added element, influencing the visual aesthetic form-the biophilic form. This in turn influences the attitude of the users of buildings and the site towards environmental problems. This aspect, however, can be tested in the future.

Author Contributions: Conceptualization, R.J.; methodology, A.J. and R.J.; validation, R.J. and A.J.; formal analysis, R.J. and A.J.; investigation, R.J.; resources, R.J. and A.J.; data curation, R.J. and A.J.; writing - original draft preparation, R.J.; writing-review and editing, R.J. and A.J.; visualization, R.J. and A.J.; supervision, A.J. All authors have read and agreed to the published version of the manuscript.

Funding: This research received no external funding.

Institutional Review Board Statement: Not applicable.

Informed Consent Statement: Not applicable.

Data Availability Statement: Data is contained within the article.

Acknowledgments: We would like to thank architects and designers from Leclercq Associés for providing photos and visuals for the article.

Conflicts of Interest: The authors declare no conflict of interest.

\section{References}

1. Global Platform for Sustainable Cities. Urban Sustainability Framework; World Bank: Washington, DC, USA, 2018. Available online: http:/ / documents1.worldbank.org/curated/en/339851517836894370/pdf/123149-Urban-Sustainability-Framework.pdf (accessed on 3 May 2021).

2. United Nations. World Urbanization Prospects: The 2014 Revision; United Nations, Department of Economic and Social Affairs, Population Division: New York, NY, USA, 2015. Available online: https://esa.un.org/unpd/wup/Publications/Files/WUP2014Report.pdf (accessed on 3 May 2021).

3. Hoornweg, D.; Sugar, L.; Gómez, C.L.T. Cities and greenhouse gas emissions: Moving forward. Environ. Urban. 2011, 23, 207-227. [CrossRef]

4. Goodland, R. The concept of environmental sustainability. Annu. Rev. Ecol. Syst. 1995, 26, 1-24. [CrossRef]

5. Haughton, G.; Hunter, C. Sustainable Cities; Routledge: London, UK, 2004.

6. Andersson, E. Urban landscapes and sustainable cities. Ecol. Soc. 2006, 11, 36. [CrossRef]

7. Bithas, K.P.; Christofakis, M. Environmentally sustainable cities. Critical review and operational conditions. Sustain. Dev. 2006, 14, 177-189. [CrossRef]

8. Moldan, B.; Janoušková, S.; Hák, T. How to understand and measure environmental sustainability: Indicators and targets. Ecol. Indic. 2012, 17, 4-13. [CrossRef]

9. Pickett, S.T.; Cadenasso, M.L.; McGrath, B. (Eds.) Resilience in Ecology and Urban Design: Linking Theory and Practice for Sustainable Cities; Springer Science \& Business Media: Berlin/Heidelberg, Germany, 2013; Volume 3, p. 499.

10. Martos, A.; Pacheco-Torres, R.; Ordóñez, J.; Jadraque-Gago, E. Towards successful environmental performance of sustainable cities: Intervening sectors. A review. Renew. Sustain. Energy Rev. 2016, 57, 479-495. [CrossRef]

11. Bibri, S.E.; Krogstie, J. Smart sustainable cities of the future: An extensive interdisciplinary literature review. Sustain. Cities Soc. 2017, 31, 183-212. [CrossRef]

12. United Nations. Rio declaration on environment and development. In Proceedings of the United Nations Conference on Environment and Development, Rio de Janerio, Brazil, 3-14 June 1992. Available online: https://www.un.org/en/development/ desa/population/migration/generalassembly/docs/globalcompact/A_CONF.151_26_Vol.I_Declaration.pdf (accessed on 25 April 2021).

13. European Cities \& Towns Towards Sustainability. The Aalborg Charter. Available online: https://sustainablecities.eu/fileadmin/ repository/Aalborg_Charter/Aalborg_Charter_English.pdf (accessed on 3 May 2021).

14. European Council of Town Planners. The New Charter of Athens; Alinea: Florence, Italy, 2003.

15. European Commision. LEIPZIG CHARTER on Sustainable European Cities; Official Journal of the European Union, 2009. Available online: https:/ / ec.europa.eu/regional_policy/sources/activity/urban/leipzig_charter.pdf (accessed on 25 April 2021).

16. European Commision. THE NEW LEIPZIG CHARTER The Transformative Power of Cities for the Common Good; Official Journal of the European Union, 2020. Available online: https:/ / ec.europa.eu/regional_policy/en/information/publications / brochures/2020/new-leipzig-charter-the-transformative-power-of-cities-for-the-common-good (accessed on 25 April 2021).

17. United Nations. United Nations Conference on Sustainable Development "The Future We Want" (UNCSD); United Nations: New York, NY, USA, 2012. Available online: https:/ / sustainabledevelopment.un.org/content/documents/733FutureWeWant.pdf (accessed on 25 April 2021). 
18. United Nations. Transforming Our World: The 2030 Agenda for Sustainable Development; United Nations: New York, NY, USA, 2015. Available online: https://www.un.org/ga/search/view_doc.asp?symbol=A/RES/70/1\&Lang=E (accessed on 25 April 2021).

19. United Nations. Paris agreement. In Proceedings of the United Nations Framework Convention on Climate Change, 21st Conference of the Parties, COP21, Paris, France, 20 November-12 December 2015. Available online: https://www.undp.org/content/ undp/en/home/presscenter/events/2015/december/COP21-paris-climate-conference.html (accessed on 25 April 2021).

20. United Nations. United Nations Decade on Biodiversity 2011-2020. Available online: https://undocs.org/A/RES/65/161 (accessed on 25 April 2021).

21. United Nations. HABITAT III. New Urban Agenda. Available online: https://europa.eu/capacity4dev/file/31483/download? token=b_Z4h8W4 (accessed on 25 November 2021).

22. United Nations. International Decade for Action, “Water for Sustainable Development" 2018-2028. Available online: https: / / undocs.org/en/A/RES/71/222 (accessed on 25 April 2021).

23. United Nations. United Nations Decade on Ecosystem Restoration 2021-2030. Available online: https://undocs.org/A/RES/73 /284 (accessed on 25 April 2021).

24. Hanna, E.; Comín, F.A. Urban Green Infrastructure and Sustainable Development: A Review. Sustainability 2021, 13, 11498. [CrossRef]

25. Mathey, J.; Rink, D. Greening brownfields in urban redevelopment. In Sustainable Built Environments; Encyclopedia of Sustainability Science and Technology Series; Loftness, V., Ed.; Springer: New York, NY, USA, 2020.

26. Hammond, E.B.; Coulon, F.; Hallett, S.H.; Thomas, R.; Hardy, D.; Kingdon, A.; Beriro, D.J. A critical review of decision support systems for brownfield redevelopment. Sci. Total Environ. 2021, 785, 147132. [CrossRef]

27. Mestre, N.; Roig, E.; Almestar, M. Beyond Nature-Based Rhetorics: A Prospect on the Potentials of Redundancy in EcologyOriented Design. Sustainability 2021, 13, 13293. [CrossRef]

28. Totaforti, S. Emerging Biophilic Urbanism: The Value of the Human-Nature Relationship in the Urban Space. Sustainability 2020, 12, 5487. [CrossRef]

29. Brand, J.L.; Augustin, S. Can We Sustain Sustainability? A Critical Synthesis of Pertinent Literature. Sustainability 2021, 13, 12753. [CrossRef]

30. Wilson, E.O. Biophilia; Harvard University Press: Cambridge, MA, USA, 1984.

31. Böhme, G. The Aesthetics of Atmospheres; Routledge: London, UK, 2016.

32. Qingjiu, S.; Maliki, N.Z. Place attachment and place identity: Undergraduate students' place bonding on campus. Procedia Soc. Behav. Sci. 2013, 91, 632-639. [CrossRef]

33. Kaplan, S. The restorative benefits of nature: Toward an integrative framework. J. Environ. Psychol. 1995, 15, 169-182. [CrossRef]

34. Kaplan, R.; Kaplan, S. The Experience of Nature: A Psychological Perspective; Cambridge University Press: Cambridge, UK, 1989.

35. Ulrich, R.S. Aesthetic and affective response to natural environment. In Behavior and the Natural Environment; Altman, I., Wohlwill, J.F., Eds.; Springer: Boston, MA, USA, 1983; Volume 6, pp. 85-125.

36. Appleton, J. The Experience of Landscape; John Wiley \& Sons: Hoboken, NJ, USA, 1975.

37. Peters, T.; D'Penna, K. Biophilic Design for Restorative University Learning Environments: A Critical Review of Literature and Design Recommendations. Sustainability 2020, 12, 7064. [CrossRef]

38. Beatley, T. Biophilic Cities: Integrating Nature into Urban Design and Planning; Island Press: Washington, DC, USA, 2011.

39. Beatley, T.; Neman, P. Biophilic Cities Are Sustainable, Resilient Cities. Sustainability 2013, 5, 3328-3345. [CrossRef]

40. Kellert, S.R.; Heerwagen, J.; Mador, M. (Eds.) Biophilic Design: The Theory, Science and Practice of Bringing Buildings to Life; John Wiley \& Sons: Hoboken, NJ, USA, 2011.

41. Kellert, S.R. Dimensions, Elements, and Attributes of Biophilic Design. In Biophilic Design: The Theory, Science, and Practice of Bringing Buildings to Life; Kellert, S.R., Heerwagen, J., Mador, M., Eds.; John Wiley \& Sons: Hoboken, NJ, USA, 2018.

42. Browning, W.; Ryan, C.; Clancy, J. 14 Patterns of Biophilic Design; Terrapin Bright Green, LLC: New York, NY, USA, 2014. Available online: https:/ / www.terrapinbrightgreen.com/reports/14-patterns/ (accessed on 5 April 2021).

43. Kellert, S.; Calabrese, E. The Practice of Biophilic Design; Terrapin Bright LLC: New York, NY, USA, 2015.

44. Røe, P.G.; Mark Luccarelli, M. Biophilic Oslo, Green Oslo Visions, Planning, and Discourse; Routledge: London, UK, 2013.

45. Tabb, P.J. Biophilic Urbanism: Designing Resilient Communities for the Future; Routledge: London, UK, 2020.

46. Andreucci, M.B.; Loder, A.; Brown, M.; Brajković, J. Exploring Challenges and Opportunities of Biophilic Urban Design: Evidence from Research and Experimentation. Sustainability 2021, 13, 4323. [CrossRef]

47. Amat, R.C.; Ismail, S.; Wahab, M.H.; Ahmad, N.H.; Rani, W.N.M.W.M. A Dimension of Biophilia in Urban Design. IOP Conf. Ser. Earth Environ. Sci. 2020, 409, 12-16. [CrossRef]

48. Lee, E.J.; Park, S.J. Toward the Biophilic Residential Regeneration for the Green New Deal. Int. J. Environ. Res. Public Health 2021, 18, 2523. [CrossRef]

49. Lee, S.; Kim, Y. A framework of biophilic urbanism for improving climate change adaptability in urban environments. Urban For. Urban Green. 2021, 61, 127104. [CrossRef]

50. Ghaziani, R.; Lemon, M.; Atmodiwirjo, P. Biophilic Design Patterns for Primary Schools. Sustainability 2021, 13, 12207. [CrossRef]

51. Abdelaal, M.S. Biophilic campus: An emerging planning approach for a sustainable innovation-conducive university. J. Clean Prod. 2019, 215, 1445-1456. [CrossRef]

52. König, A. Regenerative Sustainable Development of Universities and Cities; Edward Elgar: Cheltenham, UK, 2013 ; p. 352. 
53. International Sustainable Campus Network. Sustainable Development: Education with Purpose; 2018 Sustainable Campus Case Studies. Available online: https://international-sustainable-campus-network.org/download/521/ (accessed on 22 April 2021).

54. Ashworth, G.J.; Larkham, P.J. A heritage for Europe. The need, the task, the contribution. In Building a New Heritage. Tourism, Culture and Identity in the New Europe; Ashworth, G.J., Larkham, P.J., Eds.; Routledge: London, UK, 1994.

55. Tellis, W. Application of a case study methodology. Qual. Rep. 1997, 3, 1-19.

56. Yin, R. Case Study Research: Design and Methods, 4th ed.; Sage: Thousand Oaks, CA, USA, 2009.

57. Hafiz, K. Case study example. Qual. Rep. 2008, 13, 544-559.

58. Groat, L. Case studies and combined strategies. In Architectural Research Methods; Groat, L., Wang, D., Eds.; John Wiley \& Sons: Hoboken, NJ, USA, 2013; pp. 415-453.

59. Cornaille, J. La papeterie de la Seine 1904-2004. In Bulletin n 38-juin 2007; Sociéte d'Historie de Nanterre: Nanterre, France.

60. Girling, C.; Ronald, K. Skinny Streets and Green Neighborhoods: Design for Environment and Community; Island Press: Washington, DC, USA, 2005.

61. Le Prefet des Hauts-de-Seine. Arrete Prefectoral No 2018-184 en Date du 23 Novembre 2018 Autorisant l'Amenagement de la ZAC des Papeteries sur la Commune de Nanterre (92). Available online: https://www.hauts-de-seine.gouv.fr/index. $\mathrm{php} /$ content/download/12499/87602/file/AP+d\%27autorisation+environnementale+du+23+novembre+2018+-ZAC+des+ papeteries_Nanterre.pdf (accessed on 1 December 2020).

62. Le Prefet des Hauts-de-Seine. Arrêté Prefectoral DCPPAT No 2020-23 en Date du 21 Fevrier 2020 Complementaire de l'Arrete no 2018-184 en Date du 28 Novembre 2018 Portant Autorisation de l'Amenagement de la ZAC des Papeteries a Nanterre. Available online: https:/ / www.hauts-de-seine.gouv.fr/index.php/content/download/14924/99998/file/2020+20+02+APC+ZAC+des+ Papeteries.pdf (accessed on 1 December 2020).

63. Le Schéma Directeur de la Région Île-de-France (SDRiF). Décret No 2013-1241 du 27 Décembre 2013 Portant Approbation du Schéma Directeur de la Région d'Ile-de-France. Available online: https: / www.legifrance.gouv.fr/loda/id/JORFTEXT000028396 726/ (accessed on 1 December 2020).

64. Plan Local d'Urbanisme de la Commune de Nanterre 2015 (PLU de Nanterre). PLU Approuvé par le Conseil Municipal du 15 Décembre 2015; Départment des Hauts-de-Seine/Ville Naterre: Nanterre, France, 2015.

65. Plan Local d'Urbanisme de la Commune de Nanterre 2015 (PLU de Nanterre). PLU Approuvé par le Conseil Municipal du 15 Décembre 2015 et Mis à Jour par Arrêté en Date du 6 Avril 2021 (The Revision of the Plan from 2021). Départment des Hautsde-Seine/Ville Naterre, Nanterre, France 2021. Available online: https:/ /www.nanterre.fr/746-plan-local-d-urbanisme.htm (accessed on 15 April 2021).

66. Burtenshaw, D.; Bateman, M.; Ashworth, G.J. The European City: Western Perspectives; Routledge: London, UK, 1991.

67. Alfrey, J.; Putnam, T. The Industrial Heritage: Managing Resources and Uses; Routledge: London, UK, 2003.

68. Douet, J. (Ed.) Industrial Heritage Re-Tooled: The TICCIH Guide to Industrial Heritage Conservation; Left Coast Press: Walnut Creek, CA, USA, 2013.

69. Wicke, C.; Berger, S.; Golombek, J. (Eds.) Industrial Heritage and Regional Identities; Routledge: London, UK, 2018.

70. Monnet, A. Menaces pour "Les Papeteries de la Seine”. Écho Val Seine 2013, 67. Available online: http://valdeseinevert.org/ menaces-pour-les-papeteries-de-la-seine/ (accessed on 7 April 2021).

71. Société d'Économie Mixte d'Aménagement et de Gestion de la Ville de Nanterre (SEMNA) \& SCE Aménagement \& Environnement. Projet d'Amenagement de la ZAC des Papéteries-Commune de Nanterre (92)—Étude d'Impact; SEMNA: Nanterre, France, 2017.

72. Archives Départementales des Hauts-de-Seine. Papeterie de la Sein; AD92_GHERRAM_20190826113040. Available online: https:/ / francearchives.fr/findingaid/ef27551e3dced6dbf313279c9ac9bab0bf3cf0c2 (accessed on 7 April 2021).

73. Masson, V.; Marchadier, C.; Adolphe, L.; Aguejdad, R.; Avner, P.; Bonhomme, M.; Bretagne, G.; Briottet, X.; Bueno, B.; de Munck, C.; et al. Adapting cities to climate change: A systemic modelling approach. Urban Clim. 2014, 10, 407-429. [CrossRef]

74. Omer, A. Renewable building energy systems and passive human comfort solutions. Renew. Sustain. Energy Rev. 2008, 12, 1562-1587. [CrossRef]

75. Foster, J.; Lowe, A.; Winkelman, S. The Value of Green Infrastructure for Urban Climate Adaptation; The Center for Clean Air Policy: Washington, DC, USA, 2011.

76. Wilmers, F. Effects of vegetation on urban climate and buildings. Energy Build. 1990, 15, 507-514. [CrossRef]

77. Wong, N.-H.; Chen, Y. The role of urban greenery in high-density cities. In Designing High-Density Cities for Social and Environmental Sustainability; Ng, E., Ed.; EarthScan: London, UK, 2010; pp. 227-262.

78. Heidt, V.; Neef, M. Benefits of urban green space for improving urban climate. In Ecology, Planning, and Management of Urban Forests; Springer: New York, NY, USA, 2008; pp. 84-96.

79. Grochulska-Salak, M. Re-urbanization in a model of sustainable development of an eco-city. Acta Sci. Pol. Archit. 2021, $20,3-12$. [CrossRef]

80. Meggers, F.; Leibundgut, H.; Kennedy, S.; Qin, M.; Schlaich, M.; Sobek, W.; Shukuya, M. Reduce $\mathrm{CO}_{2}$ from buildings with technology to zero emissions. Sustain. Cities Soc. 2012, 2, 29-36. [CrossRef]

81. Roodman, D.; Lenssen, N. Worldwatch Paper \#124: A Building Revolution: How Ecology and Health Concerns are Transforming Construction; Worldwatch Institute: Washington, DC, USA, 1995. 
82. Guo, H.; Liu, Y.; Chang, W.S.; Shao, Y.; Sun, C. Energy saving and carbon reduction in the operation stage of cross laminated timber residential buildings in China. Sustainability 2017, 9, 292. [CrossRef]

83. Chen, C.X.; Pierobon, F.; Ganguly, I. Life Cycle Assessment (LCA) of Cross-Laminated Timber (CLT) produced in Western Washington: The role of logistics and wood species mix. Sustainability 2019, 11, 1278. [CrossRef]

84. Sabbah, C. Le bois à l'assaut d'un mégaprojet immobilier. Le Echos, 4 May 2017. Available online: https:/ / www.lesechos.fr/2017 /05/le-bois-a-lassaut-dun-megaprojet-immobilier-170920(accessed on 5 May 2021).

85. Missions Régionales d'Autorité Environnementale (MRAe). Avis en Date du 28 Décembre 2017 de la Mission Régionale d'Autorité Environnementale d'Île-de-France sur le Projet d'Aménagement du Site des Papeteries Situé ŕ Nanterre (Hauts-deSeine). Available online: http://www.mrae.developpement-durable.gouv.fr/IMG/pdf/171228_mrae_avis_amenagement_site_ papeteries_nanterre_92.pdf (accessed on 13 April 2021).

86. Mora, E.P. Life cycle, sustainability and the transcendent quality of building materials. Build. Environ. 2007, 42, 1329-1334. [CrossRef]

87. Magnusson, S.; Lundberg, K.; Svedberg, B.; Knutsson, S. Sustainable management of excavated soil and rock in urban areas-a literature review. J. Clean Prod. 2015, 93, 18-25. [CrossRef]

88. DRIEE Ile-de-France, Enveloppes d'Alerte des Zones Humides Avérées et Potentielles en Région Île-de-France. Available online: http:/ / carto.geo-ide.application.developpement-durable.gouv.fr/73/Zones_humides.map (accessed on 13 April 2021).

89. Plan de Prevention du Risque Inondation de la Seine dans le Département des Hauts-de-Seine (P.P.R.I.). Arrêté DRCT/1 no 200401 en Date du 9 Janvier 2004 Portant Approbation du Plan de Prevention du Risque Inondation de la Seine dans le Département des Hauts-de-Seine (P.P.R.I.), Le Prefet des Hauts-de-Seine. Available online: http:/ / www.driee.ile-de-france.developpementdurable.gouv.fr/IMG/pdf/arrete_prefectoral_09012004_ppri_92.pdf (accessed on 26 March 2021).

90. Service Assainissement des Hauts-de-Seine. Règlement du Service Départemental d'Assainissement des Hauts-de-Seine (Adopté par Délibération du 14 Décembre 2018). Available online: https://www.hauts-de-seine.fr/fileadmin/user_upload/Mon_ departement/01_Missions_et_actions/01.6_Eau/01.6.1_Assainissement/Assainissement.pdf (accessed on 26 March 2021).

91. Fletcher, T.D.; Shuster, W.; Hunt, W.F.; Ashley, R.; Butler, D.; Arthur, S.; Viklander, M. SUDS, LID, BMPs, WSUD and more-The evolution and application of terminology surrounding urban drainage. Urban Water J. 2015, 12, 525-542. [CrossRef]

92. Pour, S.H.; Abd Wahab, A.K.; Shahid, S.; Dewan, A. Low impact development techniques to mitigate the impacts of climatechange-induced urban floods: Current trends, issues and challenges. Sustain. Cities Soc. 2020, 62, 102373. [CrossRef]

93. Jóźwik, R. Rainwater Management Solutions and their Impact on Shaping Inner City Areas Undergoing Transformation (Case Study of the ZAC Clichy-Batignolles Area in Paris). J. Ecol. Eng. 2020, 21, 209-219. [CrossRef]

94. Council of Europe. European Landscape Convention. Florence, 2000. Available online: https://rm.coe.int/1680080621 (accessed on 26 April 2021).

95. Direction Régionale et Interdépartementale de l'Équipement et de l'Aménagement de la Région d'Île-de-France (DRIEA). Atlas des Paysages et des Projet Urbains des Hauts-de-Seine; l'Unité de la Boucle de la Seine, de Rueil-Malmaison à Villeneuve-laGarenne. Available online: http:/ / www.paysages.hauts-de-seine.developpement-durable.gouv.fr/portrait-de-1-unite-de-laboucle-de-la-seine-de-a82.html (accessed on 26 April 2021).

96. Direction Régionale et Interdépartementale de l'Équipement et de l'Aménagement de la Région d'Île-de-France (DRIEA). Portrait de Territoire les Deux Seine. Available online: http:/ / www.driea.ile-de-france.developpement-durable.gouv.fr/IMG/pdf/ Portrait_Les_deux_Seine_2012_cle583b24.pdf (accessed on 26 April 2021).

97. Schéma Régional de Cohérence Écologique d'Ile-de-France (SRCE). Arrêté No 2013294-0001 du 26 Septembre 2013, Préfet de la Région d'Ile-de-France. Available online: http:/ / www.driee.ile-de-france.developpement-durable.gouv.fr/le-srce-d-ile-defrance-adopte-a1685.html (accessed on 14 April 2021).

98. Muséum National d'Histoire Naturelle. Inventaire National du Patrimoine Naturel. Available online: https://inpn.mnhn.fr (accessed on 14 April 2021).

99. Eco-Environnement Conseil \& EODD. Inventory of flora and fauna in the ZAC des Papeteries de la Seine Area in Paris. In Projet d'Amenagement de la ZAC des Papéteries—Commune de Nanterre (92)—Étude d'Impact; Société d'Économie Mixte d'Aménagement et de Gestion de la Ville de Nanterre \& SCE Aménagement \& Environnement: Nanterre, France, 2017.

100. Way, T. The urban university's hybrid campus. J. Landsc. Archit. 2016, 11, 42-55. [CrossRef]

101. Scholl, K.G.; Gulwadi, G.B. Recognizing campus landscapes as learning spaces. J. Learn. Spaces 2015, 4, 53-60.

102. BASE (Landscape Architecture). Nanterre: Eco-Campus Arboretum Park. Available online: https://www.baseland.fr/en/ projets/nanterre-eco-campus-parc-de-larboretum (accessed on 24 April 2021).

103. Crane, M.; Lloyd, S.; Haines, A.; Ding, D.; Hutchinson, E.; Belesova, K.; Turcu, C. Transforming cities for sustainability: A health perspective. Environ. Int. 2021, 147, 106366. [CrossRef]

104. Berto, R. Exposure to restorative environments helps restore attentional capacity. J. Environ. Psychol. 2005, 25, 249-259. [CrossRef]

105. Douglas, O.; Lennon, M.; Scott, M. Green space benefits for health and well-being: A life-course approach for urban planning, design and management. Cities 2017, 66, 53-62. [CrossRef]

106. Barton, H.; Tsourou, C. Urbanisme et Santé; World Health Organistaion: Geneve, Switzerland, 2004.

107. Lee, A.C.; Maheswaran, R. The health benefits of urban green spaces: A review of the evidence. J. Public Health 2011, 33, $212-222$. [CrossRef] 
108. Tonne, C.; Adair, L.; Adlakha, D.; Anguelovski, I.; Belesova, K.; Berger, M.; Brelsford, C.; Dadvand, P.; Dimitrova, A.; Giles-Corti, B.; et al. Defining pathways to healthy sustainable urban development. Environ. Int. 2021, 146, 106236. [CrossRef] [PubMed]

109. Agence de la Transition Écologique (ADEME) \& Agence Régionale de Santé (ARS). Santé, Environnement E Aménagement Durable. Appel à Manifestation d'Intérêt. Retour d'Expériences Évaluation d'Impact sur la Santé (Eis) de la Reconversion du Site des Anciennes Papeteries de la Seine; Mairie de Nanterre: Nanterre, France, 2019.

110. Atelier Parisien d'Urbanisme (APUR). Projet de Reconversion du Site des Anciennes Papeteries de la Seine à Nanterre. Étude pour un Urbanisme Favorable à la Santé. Octobre 2017. Available online: https:/ / www.apur.org/sites/default/files/documents / publication/etudes/eis_nanterre.pdf (accessed on 26 January 2021).

111. Krefis, A.C.; Augustin, M.; Schlünzen, K.H.; Oßenbrügge, J.; Augustin, J. How does the urban environment affect health and well-being? A systematic review. Urban Sci. 2018, 2, 21. [CrossRef]

112. Dahlgren, G.; Whitehead, M. "The main determinants of health" model (1991). In European Strategies for Tackling Social Inequities in Health: Levelling up Part 2; Dahlgren, G., Whitehead, M., Eds.; WHO Regional Office for Europe: Copenhagen, Denmark, 2007. Available online: https://www.euro.who.int/_data/assets/pdf_file/0018/103824/E89384.pdf (accessed on 2 May 2021).

113. Barton, H.; Grant, M. A health map for the local human habitat. J. R. Soc. Promot. Health 2006, 126, 252-253. [CrossRef]

114. Moudon, A.V.; Hess, P.M.; Snyder, M.C.; Stanilov, K. Effects of site design on pedestrian travel in mixed-use, medium-density environments. Transp. Res. Rec. 1997, 1578, 48-55. [CrossRef]

115. Frank, L.D.; Pivo, G. Impacts of mixed use and density on utilization of three modes of travel: Single-occupant vehicle, transit, and walking. Transp. Res. Rec. 1994, 1466, 44-52.

116. Gehl, J. Life Between Buildings: Using Public Space; Island Press: Washington, DC, USA, 2011; p. 200.

117. Talen, E. New Urbanism and American Planning: The Conflict of Cultures; Routledge: London, UK, 2005; p. 328.

118. Plan de Déplacements Urbains d'Île-de-France (PDUIF). Approuvé par la Délibération du Conseil Régional no CR 36-14 du 19 Juin 2014. Available online: http:/ / www.pduif.fr/ (accessed on 17 April 2021).

119. Cervero, R. Public Transport and Sustainable Urbanism: Global Lesson; Science Council of Japan: Tokyo, Japan, 2006.

120. Cervero, R.; Sullivan, C. Green TODs: Marrying transit-oriented development and green urbanism. Int. J. Sustain. Dev. World Ecol. 2011, 18, 210-218. [CrossRef]

121. Plan Départemental des Itinéraires de Promenade et de Randonnée (PDIPR). Approuvé par l'Assemblée départementale Délibérante Lors de la Séance de la Commission Permanente du 15 Avril 2019. Available online: https://www.hauts-deseine.fr/fileadmin/user_upload/Mon_departement/01_Missions_et_actions/01.2_Patrimoine_vert/PDIPR/MAJ_PDIPR_ _Presentation.pdf (accessed on 1 May 2021).

122. Mohai, P.; Pellow, D.; Roberts, J.T. Environmental justice. Annu. Rev. Environ. Resour. 2009, 34, 405-430. [CrossRef]

123. Dempsey, N.; Bramley, G.; Power, S.; Brown, C. The social dimension of sustainable development: Defining urban social sustainability. Sustain. Dev. 2011, 19, 289-300. [CrossRef]

124. Plan Régional Santé Environnement (PRSE2). Arrêté No 2011208-0017 Signé par le Préfet de la Région d'Ile-de-France, Préfet de Paris le 27 Juillet 2011. Available online: http:/ / www.driee.ile-de-france.developpement-durable.gouv.fr/IMG/pdf/PRSE2_cle2 e91b1.pdf (accessed on 26 April 2021).

125. Peters, A.; Dockery, D.W.; Muller, J.E.; Mittleman, M.A. Increased particulate air pollution and the triggering of myocardial infarction. Circulation 2001, 103, 2810-2815. [CrossRef] [PubMed]

126. Medina, S.; Pascal, M.; Tillier, C. Impacts de l'Exposition Chronique Aux Particules Fines sur la Mortalité en France continentale et Analyse des Gains en Santé de Plusieurs Scénarios de Réduction de la Pollution Atmosphérique; Santé Publique: Saint-Maurice, France, 2016; p. 12. Available online: https:/ / www.santepubliquefrance.fr (accessed on 17 April 2021).

127. World Health Organization (WHO). Night Noise Guidelines for Europe; WHO: Copenhagen, Denmark, 2009; Available online: https:/ / www.euro.who.int/_data/assets/pdf_file/0017/43316/E92845.pdf (accessed on 11 July 2013).

128. Hidaka, S.; Ide, M. Sound can suppress visual perception. Sci. Rep. 2015, 29, 10483. [CrossRef] [PubMed]

129. Morillas, J.M.B.; Gozalo, G.R.; González, D.M.; Moraga, P.A.; Vílchez-Gómez, R. Noise pollution and urban planning. Curr. Pollut. Rep. 2018, 4, 208-219. [CrossRef]

130. BASOL. Base de Données BASOL sur les Sites et Sols Pollués (ou Potentiellement Pollués) Appelant Une Action Des Pouvoirs Publics, à Titre Préventif ou Curatif, SMURFIT KAPPA (Anciennes Papèteries de Nanterre). 19 May 2017. Available online: https: / / basol.developpement-durable.gouv.fr / fiche.php?page=1\&index_sp=92.0095, (accessed on 1 September 2020).

131. BASIAS, Smurfit Socar (Papeterie de la Seine). Available online: https://fiches-risques.brgm.fr/georisques/basias-detaillee/ IDF9200496 (accessed on 15 March 2021).

132. Rynska, E.D.; Oniszk-Poplawska, A.T.; Kozminska, U. Quality of resilient cities, the issue of urban waste: Waste management as part of urban metabolism. In Megacities and Rapid Urbanization: Breakthroughs in Research and Practice; IGI Global, Information Resources Management Association: Hershey, PA, USA, 2020; pp. 228-249.

133. CCI France. La Planification de la Gestion des Déchets en Ile-de-France. Available online: https://www.enviroveille.com/public/ fiches_pratiques / fiches-pratiques.html?cat_id=1\&dossier_id=128836\&fiche_id=1675802 (accessed on 15 March 2021).

134. Unité Aménagement Durable. Direction de l'Environnement. Plan Régional de Prévention et de Gestion des Déchets de Chantiers (PREDEC). Région Île-de-France. Available online: https:/ / www.actu-environnement.com/media/pdf/news-27071-predec-ildede-france-juin-2015.pdf (accessed on 15 March 2021). 
135. NUDEC. Un diagnostic déchets, en date du 06/06/2017 (réf: No RDPRIF01115). In Projet d'Amenagement de la ZAC des PapéteriesCommune de Nanterre (92)—Étude d'Impact; Société d'Économie Mixte d'Aménagement et de Gestion de la Ville de Nanterre \& SCE Aménagement \& Environnement: Nanterre, France, 2017.

136. CONTEX. Un diagnostic amiante, en date du 09/06/2017 (réf: 150-425-01). In Projet d'Amenagement de la ZAC des PapéteriesCommune de Nanterre (92)—Étude d'Impact; Société d'Économie Mixte d'Aménagement et de Gestion de la Ville de Nanterre \& SCE Aménagement \& Environnement: Nanterre, France, 2017.

137. Val de Seine Vert-Association des Hauts-de-Seine Agréée Environnement. Papeteries de la Seine: Démarrage de la reconversion. Actualités Écho Val Seine 2016, 81. Available online: http:/ / valdeseinevert.org/papeteries-de-la-seine-demarrage-de-lareconversion (accessed on 15 March 2021).

138. Cappai, F.; Forgues, D.; Glaus, M. Methodological Approach for Evaluating Brownfield Redevelopment Projects. Urban Sci. 2019, 3, 45. [CrossRef]

139. Biloria, N. From smart to empathic cities. Front. Archit. Res. 2021, 10, 3-16. [CrossRef]

140. Schadler, S.; Morio, M.; Bartke, S.; Rohr-Zanker, R.; Finkel, M. Designing sustainable and economically attractive brownfield revitalization options using an integrated assessment model. J. Environ. Manag. 2011, 92, 827-837. [CrossRef]

141. Pediaditi, K.; Doick, K.J.; Moffat, A.J. Monitoring and evaluation practice for brownfield, regeneration to greenspace initiatives: A meta-evaluation of assessment and monitoring tools. Landsc. Urban Plan. 2010, 97, 22-36. [CrossRef]

142. Chan, E.; Lee, G.K.L. Critical factors for improving social sustainability of urban renewal projects. Soc. Indic. Res. 2008, 85, $243-256$. [CrossRef]

143. Jones, D.R. 'The Biophilic University': A de-familiarizing organizational metaphor for ecological sustainability? J. Clean. Prod. 2013, 48, 148-165. [CrossRef]

144. Revell, G.; Anda, M. Sustainable urban biophilia: The case of greenskins for urban density. Sustainability 2014, 6, 5423-5438. [CrossRef]

145. Brokking, P.; Mörtberg, U.; Balfors, B. Municipal Practices for Integrated Planning of Nature-Based Solutions in Urban Development in the Stockholm Region. Sustainability 2021, 13, 10389. [CrossRef]

146. Panlasigui, S.; Spotswood, E.; Beller, E.; Grossinger, R. Biophilia beyond the Building: Applying the Tools of Urban Biodiversity Planning to Create Biophilic Cities. Sustainability 2021, 13, 2450. [CrossRef]

147. Jaszczak, A.; Kristianova, K.; Wasilewska, O.; Dunisijevic-Bojovic, D. Concepts of "Biophilia" and "Livability" in the context of social perception of public space in cities. Przestrz. Forma 2020, 42, 133-146. [CrossRef]

148. Blau, M.L.; Luz, F.; Panagopoulos, T. Urban river recovery inspired by nature-based solutions and biophilic design in Albufeira, Portugal. Land 2018, 7, 141. [CrossRef]

149. Biophilic Cities. Partner Cities. Available online: http://biophiliccities.org/partner-cities/ (accessed on 7 December 2021).

150. Novosadová, L.; Van Der Knaap, W. The role of biophilic agents in building a green resilient city; the case of Birmingham, UK. Sustainability 2021, 13, 5033. [CrossRef] 